$$
\begin{array}{ccccccc}
\text { L } & \text { E } & \text { T } & \text { u } & \text { v } & \text { о } & \text { s } \\
\hline \text { ARCHEOlogija } & 47
\end{array}
$$



Lietuvos istorijos institutas

\begin{tabular}{llllllll}
$\mathrm{L}$ & $\mathrm{I}$ & $\mathrm{E}$ & $\mathrm{T}$ & $\mathrm{U}$ & $\mathrm{V}$ & $\mathrm{O}$ & $\mathrm{S}$ \\
\hline
\end{tabular}

ARCHEOlogija 47 


\section{Leidybą finansavo}

\section{LIETUVOS MOKSLO TARYBA}

PAGAL VALSTYBINĘ LITUANISTINIŲ TYRIMŲ IR SKLAIDOS 2016-2024 METŲ PROGRAMĄ

(Finansavimo sutarties numeris S-LIP-19-4)

\section{Redaktorių kolegija / Editorial board:}

Atsakingoji redaktorė / Editor-in-chief dr. Agnè Čivilytė (Lietuvos istorijos institutas, Vilnius / Lithuanian Institute of History, Vilnius)

Atsakingosios redaktorès pavaduotoja / Assistant Editor dr. Elena Pranckènaitè (Lietuvos istorijos institutas, Vilnius / Lithuanian Institute of History, Vilnius)

Dr. Laurynas Kurila (Lietuvos istorijos institutas, Vilnius / Lithuanian Institute of History, Vilnius)

Dr. Valdis Bērziņš (Latvijos universitetas, Latvijos istorijos institutas, Ryga / University of Latvia, Institute of Latvian History, Riga)

Habil. dr. Anna Bitner-Wróblewska (Valstybinis archeologijos muziejus Varšuvoje, Lenkija / State Archaeological Museum in Warsaw, Poland)

Dr. Christoph Jahn (Baltijos ir Skandinavijos archeologijos centras, Šlèzvigas, Vokietija / Center for Baltic and Scandinavian Archaeology, Schleswig, Germany)

Prof. dr. Rimantas Jankauskas (Vilniaus universitetas, Lietuva / Vilnius University, Lithuania)

Akad. prof. dr. Eugenijus Jovaiša (Lietuvos mokslu akademija, Vilnius / Lithuanian Academy of Sciences, Vilnius)

Habil. dr. Bartosz Kontny (Varšuvos universitetas, Archeologijos fakultetas, Lenkija / Faculty of Archaeology, University of Warsaw, Poland)

Prof. dr. Valter Lang (Tartu universitetas, Estija / University of Tartu, Estonia)

Doc. dr. Algimantas Merkevičius (Vilniaus universitetas, Lietuva / Vilnius University, Lithuania)

Habil. dr. Tomasz Nowakiewicz (Varšuvos universitetas, Archeologijos fakultetas, Lenkija / Faculty of Archaeology, University of Warsaw, Poland)
Habil. dr. Grzegorz Osipowicz (Mikalojaus Koperniko universitetas, Torunè, Lenkija / Nicolaus Copernicus University, Toruń, Poland)

Dr. Gytis Piličiauskas (Lietuvos istorijos institutas, Vilnius / Lithuanian Institute of History, Vilnius)

Dr. Eve Rannamäe (Tartu universtitetas, Estija / University of Tartu, Estonia)

Dr. Andra Simniškyte (Lietuvos istorijos institutas, Vilnius / Lithuanian Institute of History, Vilnius)

Dr. Roberts Spirgis (Latvijos universitetas, Latvijos istorijos institutas, Ryga / University of Latvia, Institute of Latvian History, Riga)

Dr. Eugenijus Svetikas (Lietuvos istorijos institutas, Vilnius / Lithuanian Institute of History, Vilnius)

Dr. Andris Šnē (Latvijos universitetas, Ryga / University of Latvia, Riga)

Doc. dr. Gintautas Zabiela (Klaipédos universitetas, Lietuva / Klaipéda University, Lithuania)

Prof. dr. Šarūnas Milišauskas (Niujorko valstijos Bafalo universitetas, JAV / New York State University at Buffalo, USA)

Prof. dr. Timothy Chevral (Niujorko valstijos Bafalo universitetas, JAV / New York State University at Buffalo, USA)

Prof. dr. Johan Ling (Gioteborgo universitetas, Švedija / University of Gothenburg, Sweden)

Sekretorè / Secretary Dovilè Urbonavičiūtė-Jankauskienė

Redakcijos adresas / Editorial Board address:

Lietuvos istorijos institutas, Archeologijos skyrius

Tilto g. 17, LT-01101 Vilnius

Tel. (+370) 5 2614436, fax (+370) 52611433

e-mail: lietuvosarcheologija@gmail.com; civilytea@gmail.com

\section{Žurnalas registruotas: EBSCO Publishing: Central and Eastern European Academic Source European Reference Index for the Humanities and Social Sciences (ERIH PLUS)}




\section{TURINYS / CONTENT}

Agnè Čivilytė

Ernestine S. Elster

James Patrick Mallory
PRATARME் 7

FOREWORD 11

\section{MARIJA GIMBUTIENE் KAIP ASMENYBE் / MARIJA GIMBUTAS AS PERSONALITY}

MARIJA GIMBUTAS, HER EXCAVATIONS, AND THE CONCEPT OF OLD EUROPE / MARIJA GIMBUTIENĖ, ARCHEOLOGINIAI KASINĖJIMAI IR SENOJI EUROPA .15

MARIJA GIMBUTAS IN THE CLASSROOM, FIELD AND OFFICE: A SHORT PERSONAL REMINISCENCE / MARIJA GIMBUTIENE KLASĖJE, KASINĖJIMUOSE IR KABINETE: TRUMPI ASMENINIAI PRISIMINIMAI .31

Kornelija Jankauskaitė MARIJA GIMBUTIENÉ: KELIAUTOJA IR TYRĖJA / MARIJA GIMBUTAS: TRAVELLER AND RESEARCHER .43

\section{STRAIPSNIAI / ARTICLES}

Šarūnas Milišauskas MARIJA GIMBUTAS (GIMBUTIENĖ): THE BALTIC GODDESS .55 MARIJA GIMBUTIENĖ: BALTŲ DEIVE். .88

Julia Mattes

ANTHROPOMORPHIC FIGURINES, GYNOCENTRISM AND GIMBUTAS' RECEPTION INSIDE ARCHAEOLOGY AND BEYOND .91

ANTROPOMORFINĖS FIGŪRĖLĖS, GINOCENTRIZMAS IR MARIJOS GIMBUTIENĖS IDĖJOS ARCHEOLOGIJOJE BEI UŽ JOS RIBŲ 123

MELLAART, GIMBUTAS, GODDESSES, AND ÇATALHÖYÜK: EARLY ASSUMPTIONS AND RECENT PERSPECTIVES ON THE ÇATALHÖYÜK FINDS 125

MELLAARTAS, GIMBUTIENĖ, DEIVĖS IR ČATAL HIUJUKAS: PIRMOSIOS PRIELAIDOS IR NAUJAUSIA RADINIŲ IŠ ČATAL HIUJUKO APŽVALGA 143 
Sharada Srinivasan

Rasa Banytè-Rowell

Florin Gogâltan

Gytis Piličiauskas Edvardas Simčenka Justina Kozakaitè Žydrūnè Miliauskienė Giedrè Piličiauskienè Harry Kenneth Robson

Janusz Czebreszuk Agnè Čivilytė

Paulius Gritènas

Artūras Dubonis
GODDESS WORSHIP AND THE DANCING FORM: EXPLORING RITUAL IN INDIAN PREHISTORY AND SOUTH INDIAN ANTIQUITY 145 DEIVĖS GARBINIMAS IR ŠOKIO JUDESIO FORMA: RITUALAI INDIJOS PRIEŠISTORĖJE IR PIETŲ INDIJOS ANTIKOJE 164

MARIJA GIMBUTAS’ DISSERTATION AND ITS VALUE:

BURIAL CUSTOMS IN THE ROMAN IRON AGE. 167 MARIJOS GIMBUTIENĖS DISERTACIJA IR JOS SVARBA: ROMĖNIŠKOJO LAIKOTARPO LAIDOSENA 185

TRANSYLVANIA AND THE OF INDO-EUROPEAN MIGRATION PROBLEM. THE ROMANIAN PARADIGM 187 TRANSILVANIJA IR INDOEUROPIEČIŲ MIGRACIJOS PROBLEMA. RUMUNIJOS PARADIGMA 207

DONKALNIO IR SPIGINO KAPINYNŲ AKMENS AMŽIAUS ŽMONIŲ KILMÉ IR MOBILUMAS STRONCIO IZOTOPŲ ANALIZĖS DUOMENIMIS. 209

THE ORIGINS AND MOBILITY PATTERNS OF STONE AGE HUMANS FROM THE DONKALNIS AND SPIGINAS BURIAL GROUNDS ACCORDING TO STRONTIUM ISOTOPE ANALYSIS. . .232

PROFESSOR MARIJA GIMBUTAS' ADVENTURE WITH PREHISTORIC AMBER AND THE RESULTS FOR US. 235 MARIJOS GIMBUTIENÉS PRIEŠISTORINIO GINTARO TYRINĖJIMAI IR JŲ REIKŠMĖ ŠIANDIEN 247

\section{KITAIP APIE ARCHEOLOGIJĄ /} ALTERNATIVE PERCEPTIONS OF ARCHAEOLOGY

FILOSOFIJA KAIP ARCHEOLOGIJA 249

\section{RECENZIJOS / REVIEWS}

RYTIS JONAITIS, IRMA KAPLŪNAITE்.

SENKAPIS VILNIUJE, BOKŠTO GATVËJE. XIII-XV A.

LAIDOSENOS LIETUVOJE BRUOŽAI. .253

AUTORIŲ DE்MESIUI 259

GUIDELINES FOR AUTHORS 263 


\title{
DONKALNIO IR SPIGINO KAPINYNŲ AKMENS AMŽIAUS ŽMONIŲ KILMĖ IR MOBILUMAS STRONCIO IZOTOPŲ ANALIZĖS DUOMENIMIS*
}

\author{
GYTIS PILIČIAUSKAS ${ }^{1}$, EDVARDAS SIMČENKA ${ }^{2}$, JUSTINA KOZAKAITE் ${ }^{3}$, \\ ŽYDRŪNĖ MILIAUSKIENE $\dot{H}^{4}$, GIEDRE PILIČIAUSKIENË ${ }^{5}$, HARRY KENNETH ROBSON ${ }^{6}$
}

${ }^{1}$ Archeologijos skyrius, Lietuvos istorijos institutas, Tilto g. 17, 01101 Vilnius, el. paštas: gytis.piliciauskas@gmail.com

${ }^{2}$ Archeologijos skyrius, Lietuvos istorijos institutas, Tilto g. 17, 01101 Vilnius, el. paštas: edw753@gmail.com

${ }^{3}$ Medicinos fakultetas, Vilniaus universitetas, M. K. Čiurlionio g. 21, 03101 Vilnius, el. paštas: justina.kozakaite@mf.vu.lt

${ }^{4}$ Medicinos fakultetas, Vilniaus universitetas, M. K. Čiurlionio g. 21, 03101 Vilnius, el. paštas: zydrune.miliauskiene@mf.vu.lt

${ }^{5}$ Archeologijos katedra, Vilniaus universitetas, Universiteto g. 7, 01513 Vilnius, el. paštas: giedrepils@gmail.com

${ }^{6}$ BioArCh, Department of Archaeology, University of York, Heslington, York YO10 5DD, UK, el. paštas: harry.robson@york.ac.uk

Priešistoriniu žmoniu palaiku stroncio izotopu santykio analizė $\left({ }^{87} \mathrm{Sr}{ }^{86} \mathrm{Sr}\right)$ leidžia ịvertinti ju mobiluma ir identifikuoti pirmos kartos imigrantus, tačiau jos potencialas stipriai priklauso nuo tiriamo regiono geologijos heterogeniškumo ir biologiškai prieinamo stroncio ${ }^{87} \mathrm{Sr}{ }^{86} \mathrm{Sr}$ santykio variacijos pažinimo. Lietuvos archeologijoje stroncio izotopu analize pirma karta panaudota tik 2019-2020 m. Šiame straipsnyje aptarsime šio metodo taikymo galimybes pietryčių Baltijos regione, kurias iliustruosime Donkalnio ir Spigino akmens amžiaus kapinynu buvusiose Biržulio ežero salose tyrimu.

Reikšminiai žodžiai: stroncio izotopų analizè, migracija, mobilumas, akmens amžius, Biržulio ežeras.

Whilst the analysis of strontium isotope ratios $\left({ }^{87} \mathrm{Sr} /{ }^{86} \mathrm{Sr}\right)$ of human remains enables mobility patterns and migration events to be identified archaeologically, its potential is dependent on the heterogeneity of the underlying geology in the research area, and the knowledge of ${ }^{87} \mathrm{Sr} /{ }^{86} \mathrm{Sr}$ ratio variation in the biologically available strontium. In Lithuanian archaeology, strontium isotope analysis has only been relatively recently undertaken (2019-2020). In this paper we discuss the potential of the method, and its application to materials from the Stone Age burial grounds of Donkalnis and Spiginas located on former islands in the Lake Biržulis region, western Lithuania.

Keywords: Strontium isotope analysis, migration, mobility, Stone Age, Lake Biržulis.

\section{IVADAS}

Stroncio izotopų $\left({ }^{87} \mathrm{Sr} /{ }^{86} \mathrm{Sr}\right)$ analizè jau daugiau nei tris dešimtmečius sèkmingai taikoma žmonių ir gyvūnų mobilumo praeityje tyrimuose (Ericson 1985; Price et al. 1994; Shaw et al. 2010; Knudson et al. 2012; Gregoricka 2013). Metodo esmè glūdi gyvų organizmų gebejjime kaupti stroncị audiniuose, taip pat ir labai tvirtame ir gerai išliekančiame dantų emalyje. Stroncis turi 4 izotopus, iš kurių ${ }^{87} \mathrm{Sr}$ yra radiogeniškas ir susidaro iš ${ }^{87} \mathrm{Rb}$ esant 48,8 milijardo metų skilimo pusperiodžiui. Skirtingos kilmès uolienos pasižymi nevienodu ${ }^{87} \mathrm{Sr} /{ }^{86} \mathrm{Sr}$ santykiu - senesnių jis aukštesnis. Gyviems organizmams prieinamas stroncis patenka i vandenị ir dirvožemị daugiausia iš dūlančių uolienų, po to ị augalus ir gyvūnus, $\mathrm{o}^{87} \mathrm{Sr} /{ }^{86} \mathrm{Sr}$ izotopų santykis išlieka pastovus. Kadangi mineralizavęsis dantų emalis nebekinta, jis išlaiko

\footnotetext{
${ }^{*}$ Straipsnis parengtas finansuojant Lietuvos mokslo tarybai (S-MIP-20-49).
} 
toki patị ${ }^{87} \mathrm{Sr} /{ }^{86} \mathrm{Sr}$ santykị, kuris buvo ịrašytas dančiui formuojantis vaikysteje. Šị santykị nustačius dantų emalyje ir, jị lyginant su biologiškai prieinamo stroncio santykiu gyvūnijoje, augalijoje, vandenyje ir dirvožemyje, itmanoma nustatyti, ar individas gyveno tam tikrame regione, ar maitinosi jo maistu tiriamam dančiui formuojantis (Bentley 2006; Montgomery 2010; Szostek et al. 2015; Holt et al. 2021). Taigi, stroncio izotopų analizè leidžia identifikuoti pirmosios kartos imigrantus, tačiau tam yra būtina sąlyga, kad biologiškai prieinamo stroncio izotopų signalai būtų skirtingi gimimo/vaikystès ir mirties/ palaidojimo vietose. Daugybiniais to paties danties emalio mėginių poèmiais galima nustatyti vidinę ${ }^{87} \mathrm{Sr} /{ }^{86} \mathrm{Sr}$ variaciją, rodančią chronologinę kelerių metų seką danties emaliui augant ir mineralizuojantis (Balasse 2002; 2003). Ši variacija padeda ne tik nustatyti, ar individas vietinis, tačiau ir sužinoti, kaip jis judejo per tuos kelerius metus vaikysteje, kai formavosi tiriamas dantis (e. g. Glykou et al. 2018; Boethius et al. 2021).

Iki XXI a. pradžios archeologijoje žmonių migracijos ir mobilumas dažniausiai buvo įrodinejjami tiriant daiktus, jų formas, sudètị, gamybos būdus, žaliavas. Tačiau daiktai gali keliauti tūkstančius kilometrų mainų būdu, gali būti kopijuojami, kaip ir jų gamybos technologijos. Tad labai svarbūs archeologijai genetinių tyrimų rezultatai, kurie visai neseniai atskleidè, kad Europoje, ịskaitant ir rytinę Baltijos pakrantę, neolite ir bronzos amžiuje migracijų vaidmuo buvo itin reikšmingas (Haak et al. 2015; Allentoft et al. 2015; Olalde et al. 2018; Mathieson et al. 2018; Saag et al. 2021). Stroncio izotopų metodas priešistorinio mobilumo studijoms irgi gali būti itin naudingas. Jis galètų padèti dar daugiau sužinoti apie Lietuvos akmens amžiaus žmonių kilmę, leistų identifikuoti pirmuosius migrantus ir sezoninio mobilumo atvejus, nustatyti bendrąsias mobilumo kaitos tendencijas ilgalaikèje perspektyvoje, tačiau iki pat 2019-2020 m. tai padaryti nebuvo bandoma. Lietuvos mokslo įstaigos nematuoja ${ }^{87} \mathrm{Sr} /{ }^{86} \mathrm{Sr}$ santykio, nes neturi tam reikalingos įrangos, tačiau tai, greičiausiai, nebuvo pagrindinè priežastis, kodèl stroncio izotopų analizè Lietuvos archeologiją pasiekè tik po 30 metų, skaičiuojant nuo pirmųjų sèkmingų jos pritaikymo archeologijoje atvejų kitose šalyse. Pavyzdžiui, C ir N izotopų analizè jau daugiau nei 10 metų yra tapusi iprastu metodu paleodietos tyrimuose Lietuvoje, nors pirmieji matavimai irgi vykdyti tik užsienio laboratorijose (Antanaitis-Jacobs et al. 2009; Piličiauskas et al. 2017a; 2017b). Spètume, kad stroncio izotopų analizè Lietuvos archeologus ilgą laiką gąsdino didele laboratorinių tyrimų kaina ir nežinojimu, kiek metodas pasirodys veiksmingas teritorijoje, kurią visą dengia ledynų nuogulos. Be to, norint žinoti, iš kur atvyko nevietiniai individai, reikalingas ${ }^{87} \mathrm{Sr} /{ }^{86} \mathrm{Sr}$ santykio biosferoje žemėlapis, apimantis plačias teritorijas. Deja, tokie tyrimai kol kas nevyko Baltarusijoje ir Kaliningrado srityje. ŠR Lenkijoje publikuotos tik natūralaus mineralinio vandens ${ }^{87} \mathrm{Sr} /{ }^{86} \mathrm{Sr}$ vertès (Voerkelius et al. 2010); Latvijoje - tik trijų sraigių kiautelių, o ŠV Rusijoje biosferos ${ }^{87} \mathrm{Sr} /{ }^{86} \mathrm{Sr}$ fonas nustatytas tik Senosios Ladogos gyvenvieteje (Price et al. 2020). Šiek tiek daugiau duomenų apie biosferos stroncio izotopų signalus neseniai pasirodè Estijoje, kur pabandyta identifikuoti migrantus bronzos ir ankstyvojo geležies amžiaus, taip pat vikinginio laikotarpio kapuose (Oras et al. 2016; Price et al. 2020). Taigi, dar nepradejus tyrimų stroncio izotopų studijų rezultatyvumas Lietuvoje galejjo atrodyti gana miglotas.

Lietuvoje pirmasis žingsnis, tiksliau - du žingsniai, buvo žengti 2020-2021 m. Beveik vienu metu pradèti 2 moksliniai projektai, finansuojami Lietuvos mokslo tarybos ir ${ }^{87} \mathrm{Sr} /{ }^{86} \mathrm{Sr}$ analizę numatantys kaip pagrindinị instrumentą praeities žmonių ir gyvūnų mobilumui pažinti. Pirmasis projektas, vadovaujamas G. Piličiauskienès (2019-2022 m., Žmonès ir žirgai Tautu kraustymosi laikotarpio (IV-VI a.) Lietuvoje Sr ir O stabiliuju izotopu duomenimis: kilmé ir socialinis kontekstas), tyrẻ žmonių ir žirgų kilmę geležies amžiuje. Antrasis, vadovaujamas šio 
straipsnio pirmojo autoriaus (2020-2022 m., Žmoniu mobilumas akmens ir bronzos amžiuje stabiliuju izotopu tyrimu duomenimis), nusitaike ì akmens ir bronzos amžiaus žmonių mobilumą. Šis straipsnis iš esmès remiasi antrojo projekto rezultatais. Visi jie bus publikuoti moksliniuose straipsniuose anglų kalba, o šio straipsnio lietuvių kalba tikslas yra siauresnis - supažindinti Lietuvos skaitytoją su mums dar naujo metodo taikymo galimybėmis jas atskleidžiant Biržulio ežero regiono pavyzdžiu. Prie šio ežero esančiuose Spigino ir Donkalnio kapinynuose palaidoti žmonès pasirodè esantys tinkami iškeltam tikslui igyvendinti dèl didžiulès ${ }^{87} \mathrm{Sr} /{ }^{86} \mathrm{Sr}$ santykio variacijos ir interpretacijos įvairovès.

Taigi, šiame straipsnyje pateikiamos 13-os mezolito, subneolito ir neolito žmonių iš Donkalnio ir Spigino kapinynų ${ }^{87} \mathrm{Sr} /{ }^{86} \mathrm{Sr}$ verčių kreivès, pristatomas iš 9 archeologinių gyvūnų sudarytas Biržulio ežero regiono biologiškai prieinamo stroncio ${ }^{87} \mathrm{Sr} /{ }^{86} \mathrm{Sr}$ fonas, identifikuojami nevietinès kilmès individai, vertinamas atskirų individų mobilumo laipsnis ir pobūdis vaikysteje, pasiūlomos labiausiai tikètinos nevietinių individų kilmès vietos, aptariamos metodo taikymo Lietuvoje ir kaimyniniuose kraštuose galimybès ir sunkumai.

\section{METODAI IR ME்GINIAI}

Stroncio izotopu santykis $\left({ }^{87} \mathrm{Sr} /{ }^{86} \mathrm{Sr}\right)$ buvo matuojamas dviem metodais. Lazerine abliacija - multikolektoriumi - induktyviai susietos plazmos masių spektrometrija (angl. laser ablation-multi collectorinductively coupled plasma-mass spectrometry; toliau tekste - LA-MC-ICP-MS) iš danties emalio buvo imami daugybiniai méginiai. Kadangi įrodyta, kad danties emalyje ${ }^{87} \mathrm{Sr} /{ }^{86} \mathrm{Sr}$ variacija atspindi chronologinę seką, kai vyko emalio augimas ir mineralizacija (Balasse 2002; 2003; Lazzerini et al. 2021), siekiant ne tik identifikuoti nevietinès kilmès individus, tačiau ir sužinoti, kaip jie judejo vaikystèje, žmonių dantų tyrimui buvo pasirinkta būtent LA-MC-ICP-MS.
Gyvūnų dantų emalis buvo tirtas taikant izotopų praskiedimo - terminès jonizacijos masių spektrometriją (angl. isotope dilution-thermal ionization mass spectrometry; toliau tekste - ID-TIMS). Šis metodas tikslesnis, o daugybiniai gyvūnų vieno danties tyrimai nebuvo reikalingi. Tiek LA-MC-ICP-MS, tiek ID-TIMS buvo atliktos toje pačioje mokslinių tyrimų institucijoje - Švedijos gamtos istorijos muziejaus Stokholme Geomokslų departamente.

Žmonių dantys buvo paimti iš Vilniaus universiteto Medicinos fakulteto Anatomijos, histologijos ir antropologijos katedros saugyklų, o archeologinių gyvūnų dantys - iš Vilniaus universiteto Istorijos fakulteto zooarcheologinès medžiagos saugyklos. Iš keturių Spigino kapinyno kapų dantys buvo išlikę dviejuose - 2- ir 4-ame. Donkalnyje iš 14-os identifikuotų individų (įskaitant suardytus kapus) 11-os dantys buvo išlikę. Tad iš viso tirta 13-os žmonių 13 dantų.

Renkantis žmonių dantis pirmenybė teikta anksčiausiai susiformuojantiems nuolatiniams krūminiams dantims M1 ir M2. Jų nesant dviem atvejais tirtas M3 ir kaplys P2. Radiografiniais ir histologiniais tyrimais nustatyta, kad žmogaus M1 danties emalis visiškai susiformuoja 0-3, M2 - 3-6, M3 8-11, P2 - 2-6 gyvenimo metais (Massler et al. 1941; Reid, Dean 2006). Taigi, mūsų tirtų dantų ${ }^{87} \mathrm{Sr} /{ }^{86} \mathrm{Sr}$ santykio variacijos kreivès atspindi daugiausia ankstyvąją vaikystę - 0-6 gyvenimo metus.

Šiame straipsnyje naudotos ${ }^{14} \mathrm{C}$ datos buvo kalibruotos $\mathrm{OxCal} 4.4$ programa naudojant IntCal20 atmosferos kreivę (Bronk Ramsey 2009; Reimer et al. 2020), o kalibruotos datos yra pateikiamos kaip 95,4\% tikimybès intervalai.

\section{BIRŽULIO EŽERO GYVENVIETĖS IR KAPAI}

Prie Biržulio ežero, Telšių r., yra žinomi Donkalnio ir Spigino akmens amžiaus kapinynai, taip pat 
rasta daug akmens ir bronzos amžių gyvenviečių. Šiuos paminklus 1980-1990 m. surado ir tyrinèjo Adomas Butrimas (Butrimas ir kt. 1985; Butrimas 1992; 2019; Butrimas, Ostrauskienè 2004). $2016 \mathrm{~m}$. Daktariškès 5 gyvenvietę tyrè G. Piličiauskas. Ji yra pati vertingiausia, nes vienintelè turi ežero priekrantèje susidariusị stratifikuotą subneolito - ankstyvojo bronzos amžiaus archeologinị sluoksnị (Piličiauskas 2018), joje gerai išlikusi kaulinè medžiaga, kuri ir buvo panaudota šiame darbe stroncio izotopų santykio fonui Biržulio ežero apylinkèse nustatyti.

Spigino kapinynas yra keiminèje $110 \times 40 \mathrm{~m}$ dydžio ir iki $9 \mathrm{~m}$ aukščio kalvoje, kuri kadaise buvo ežero sala. Keimo šlaitai labai statūs, o viršūnèje plokštumõs laidoti labai maža, tad nenuostabu, kad čia aptikti tik 4 kapai. Jie pavadinti nr. 1-4 ir datuoti atitinkamai 4442-4243, 2132-1749, 6814-6461, 6442-6227 cal BC (Piličiauskas, Heron 2015; Piličiauskas et al. 2017b; Antanaitis-Jacobs et al. 2009; Butrimas 1992). Kapų ${ }^{14} \mathrm{C}$ datos rodo, kad saloje laidota ne mažiau kaip 4500 metų - mezolite (kapai 3 ir 4), subneolite (kapas 1) ir neolite (kapas 2).

Donkalnio kapinynas, kaip ir Spigino, irgi yra keiminejje kalvoje, kadaise buvusioje sala arba pusiasaliu, $170 \times 50 \mathrm{~m}$ dydžio ir $5 \mathrm{~m}$ aukščio. Donkalnis yra žemesnis už Spiginą, jo viršūnè plokštesnè ir didesnio ploto. Čia aptikta ne tik daugiau kapų, bet ir akmens bei geležies amžiaus gyvenviečių liekanų (Butrimas ir kt. 1985). Buvo ištirti 7 kapai, taip pat surinkti dar 6 žmonių palaikai iš jau anksčiau kasant žvyrą suardytų kapų. Kapai pavadinti nr. 1-7, o suardytų kapų griaučiai - asmenimis I-VI. Praejjus daug metų po lauko tyrimų kape nr. 5 surinkti kaulai buvo priskirti 2 individams, maždaug $7 \mathrm{~m}$. vaikui ir kūdikiui (Piličiauskas et al. 2017b), tad iš viso Donkalnyje palaidota ne mažiau kaip 14 žmonių. Visi jie kaip ir Spigine šiandien yra datuoti tiesiogiai ${ }^{14} \mathrm{C}$ metodu, kai kurie - po kelis kartus (Antanaitis-Jacobs et al. 2009; Piličiauskas, Heron 2015; Piličiauskas et al. 2017b; Butrimas 2019), taip pat iskaitant rastuosius suardytuose kapuose (Simčenka et al., rengiama). Kaip ir Spigine, Donkalnyje irgi buvo laidota labai ilgai, mažiausiai 3000 m., nors neolito kapų čia nebuvo rasta. Jeigu mezolito ir subneolito riba laikysime 5000 cal BC', mezolitui skirtini kapai 2, 4, 5 ir suardytas kapas V. Subneolitu buvo datuoti kapai 1, 3, 6, 7 ir asmenys I-IV, VI iš suardytų kapų. Žmogaus šlaunikaulis iš kapo 7 visai neseniai buvo datuotas 3521-3371 cal BC (Simčenka et al., rengiama), tad nei anksčiau datuotas žvèries kabutis (5374-4939 cal BC; Piličiauskas 2017b), nei lokio žandikaulis (3012-2875 cal BC; Butrimas 2019) su šiuo kapu greičiausiai nesusiję. Kape buvo palaidotas $>45 \mathrm{~m}$. vyras, kurio dieta pagal C ir N izotopų signalus buvo mišri (1 pav.). Biržulio ežero gèlo vandens rezervuaro efektas galèjęs būti 250-800 m. (Piličiauskas 2018; neskelbti šiuolaikinių žuvų duomenys), tad kaulo kolageno datą teoriškai jis galejjo pasendinti $400 \mathrm{~m}$. Vis dèlto genetiniai duomenys leidžia tvirtai teigti, kad kapo 7 vyras - medžiotojų-rinkèjų atstovas, nesusijęs su Virvelinès keramikos kultūra (Mittnik et al. 2018) ir tikriausiai gyvenęs pačioje subneolito pabaigoje.

Donkalnio ir Spigino kapinynuose palaidotų žmonių dieta yra ištirta. C ir N izotopų kaulo kolagene tyrimai parodé, kad daugumos akmens amžiaus žmonių dietoje vyravo gèlavandenis maistas (Antanaitis-Jacobs et al. 2009; Piličiauskas et al. 2017b; Simčenka et al., rengiama). Išskirtiniai yra subneolitui skiriami Donkalnio individai 7 ir III bei neolitinis Spigino individas 2, kurių baltyminèje dietoje vyravo arba lygiavertę gèlavandeniam maistui dalị sudarè sausumos produktai (1 pav.).

Buvo publikuoti Donkalnio kapuose 1, 4, 6, 7 ir Spigino kapuose 1, 2, 4 palaidotų žmonių genomo

1 Šiame darbe naudota tokia Lietuvos akmens ir bonzos amžių periodizacija: mezolitas (9000-5000 cal BC), subneolitas (5000-900 cal BC), neolitas (2900-1800 cal BC), ankstyvasis bronzos amžius (1800-1100 cal BC), vèlyvasis bronzos amžius (1100-500 cal BC) 


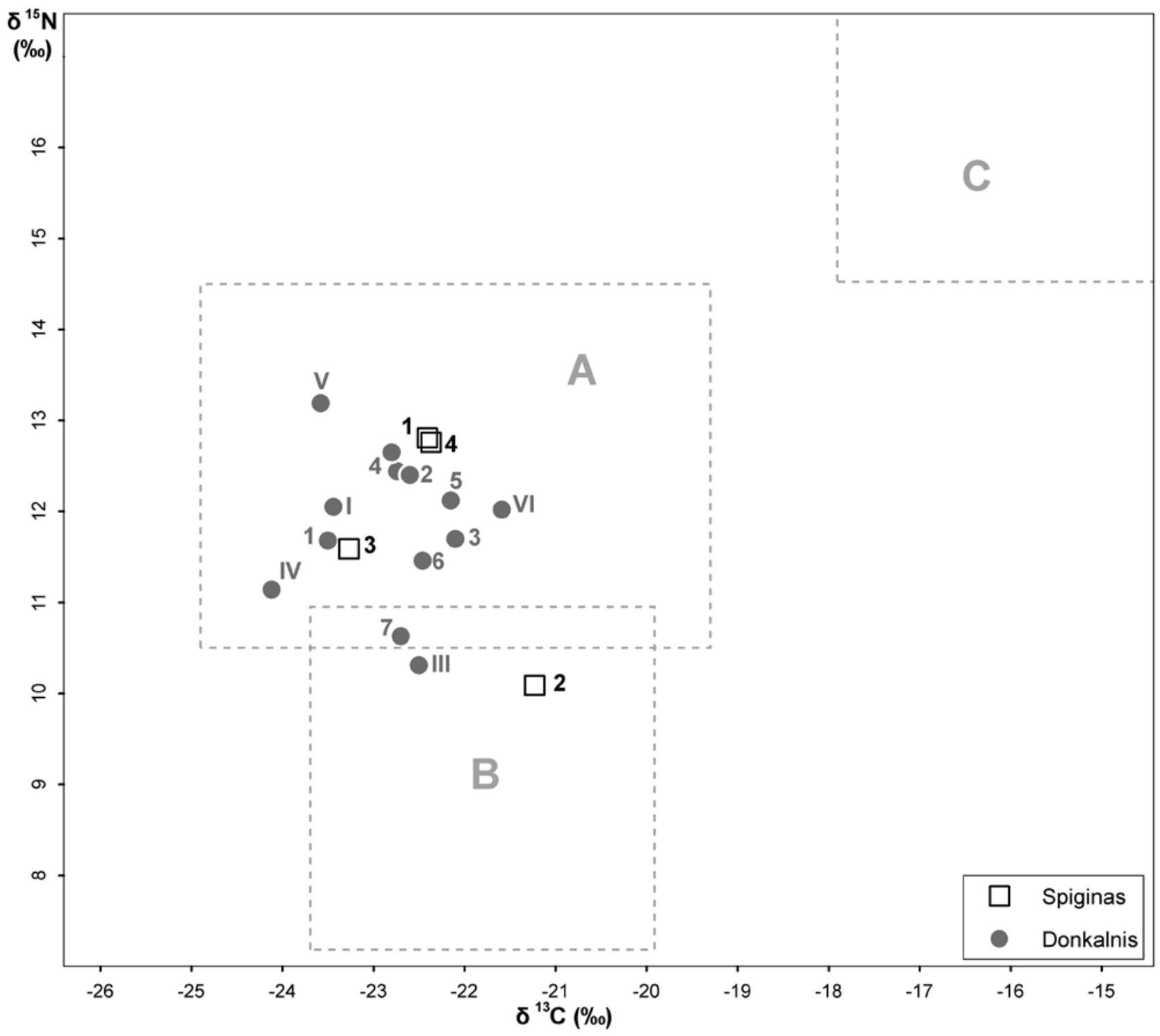

1 pav. Spigino ir Donkalnio žmonių dieta pagal $\delta^{13} \mathrm{C}$ ir $\delta^{15} \mathrm{~N}$ vertes kaulo kolagene pagal Antanaitis-Jacobs et al. (2009), Piličiauskas et al. (2017b), Simčenka et al. (rengiama). Tikètinos maisto grupių vartotojų zonos apibrèžtos punktyru: A - gèlavandenių žuvų, B - žolèdžių ir šernų, C - jūrinių žuvų ir ruonių. G. Piličiausko brèž.

Fig. 1. Stable isotope data $\left(\delta^{13} \mathrm{C}\right.$ and $\left.\delta^{15} \mathrm{~N}\right)$ obtained from human bone collagen from the burial grounds of Donkalnis and Spiginas. Data from Antanaitis-Jacobs et al. (2009), Piličiauskas et al. (2017b), Simčenka et al. (in prep). The expected ranges for the consumers of freshwater fish (A), herbivores and boars (B), and marine fish and seals (C) are shown. Drawing by G. Piličiauskas 
duomenys (Bramanti et al. 2009; Mittnik et al. 2018). Biržulio ežero mezolito ir subneolito medžiotojai, palaidoti Spigino 1, 4 ir Donkalnio 1, 6 kapuose, pasirodè esantys labai artimi vakarų medžiotojams-rinkejjams, o su rytų medžiotojais-rinkejjais yra siejama 5-30 \% jų genomo. Išsiskiria Donkalnio kapas 4, kuriame mezolite palaidotas vyras neturejo jokios giminystès su rytų medžiotojais-rinkèjais (Mittnik et al. 2018, fig. 3).

\section{BIRŽULIO EŽERO APYLINKIŲ GEOLOGIJA IR BIOLOGIŠKAI PRIEINAMO STRONCIO IZOTOPINIS FONAS}

Biržulio ežero apylinkių reljefas ir paviršiniai nuosėdų sluoksniai kaip ir beveik visoje Lietuvoje susidarè per paskutinị ledynmetị ir holocene. Ežeras slūgso Tverų moreniniame kalvyne. I rytus nuo ežero aptinkami fliuvioglacialiniai smèliai ir žvyrai - tai Biržulio fliuvioglacialinis duburys. Pietuose ir rytuose vyrauja moreniniai priemoliai (2 pav.). Nuosèdinès prekvartero uolienos Lietuvos aukštumose slūgso labai giliai, 100 ar net daugiau metrų gylyje (Aleksa 2007). Biržulio ežero apylinkèse nesant gilių slènių ir atodangų prekvartero uolienų itaka biosferos stronciui negali būti žymi. Pagrindinis stroncio dirvožemyje ir paviršiniame vandenyje šaltinis yra ledyninėse nuogulose. Šios susidarè iš įvairių periodų jūrinių nuogulų, dažnai karbonatingų, nugremžtų slenkančių ledynų dabartinès Lietuvos ir Latvijos teritorijose, taip pat iš eroduotų prekambro magminių ir metamorfinių uolienų, ledyno atvilktų iš vidurio Švedijos (Boulton et al. 2001). Šių sudètinių dalių proporcijos nevienodos. Kartais minima, kad ị Lietuvą iš Skandinavijos atvilktos nuosèdos gali sudaryti apie $25 \%$ moreninio priemolio (Kudaba 1983). Prekambro uolienų stroncis vidurio ir šiaurès Švedijoje yra labai radiogeniškas $\left({ }^{87} \mathrm{Sr} /{ }^{86} \mathrm{Sr}=0,72-0,74\right)$, o įvairaus laiko jūrinių nuosėdų stroncis, priešingai, yra mažai radiogeniškas (0,7073-0,7093) (Löfvendahl et al. 1990; Boethius et al. 2021; McArthur et al. 2001;
Veizer et al. 1997; Diener et al. 1996; Cramer et al. 2011; Edwards et al. 2015). Taigi, nors biologiškai prieinamo stroncio ${ }^{87} \mathrm{Sr} /{ }^{86} \mathrm{Sr}$ labiausiai priklauso nuo pamatinès uolienos, Biržulio ežero apylinkèse, kaip ir visoje Lietuvoje, jis negali būti nuspejamas tik iš geologinès informacijos. ${ }^{87} \mathrm{Sr} /{ }^{86} \mathrm{Sr}$ priklauso nuo dviejų skirtingo radiogeniškumo stroncio šaltinių indèlio ir gali svyruoti didelèje amplitudeje.

Norint identifikuoti nevietinius individus taikant stroncio izotopų analizę, buvo būtina sužinoti Biržulio ežero apylinkių biologiškai prieinamo stroncio ${ }^{87} \mathrm{Sr} /{ }^{86} \mathrm{Sr}$ variaciją. Šiam uždaviniui pasirinkome archeologinius gyvūnus. Gyvūnai gerai niveliuoja anomalines, labai aukštas arba žemas ${ }^{87} \mathrm{Sr} /{ }^{86} \mathrm{Sr}$ vertes, nes jie maitinasi skirtingose regiono vietose (Bentley 2006). ${ }^{87} \mathrm{Sr} /{ }^{86} \mathrm{Sr}$ archeologinių gyvūnų dantų emalyje nèra paveiktas nei užteršto lietaus ar nuotekų, nei iš nevietinių medžiagų pagamintų trąšų, kurios i Lietuvos laukus imtos masiškai pilti tik XX a. 2 -oje puseje. Todèl projekte buvo numatyta ${ }^{87} \mathrm{Sr} /{ }^{86} \mathrm{Sr}$ aplinkos fonus skirtingiems regionams kurti būtent iš archeologinių gyvūnų, jeigu įmanoma, mažiau migruojančių. Biržulio ežero regionui parinkome zooarcheologinius mėginius iš Daktariškès $5 \mathrm{gy}$ venvietès ( $n=5$; subneolitas ir ankstyvasis bronzos amžius) ir Varnių senamiesčio ( $n=4$; XVI-XVIII a.) (1 lent.). Daktariškès 5 gyvenvietè nuo Donkalnio ir Spigino kapinynų nutolusi atitinkamai 2,5 ir 3,2, nuo Varnių miestelio - 7,8 ir $4 \mathrm{~km}$ (2 pav.). Taigi, abi zooarcheologinès medžiagos radimvietès yra nutolusios nuo kapinynų ne daugiau kaip vienos dienos kelionès su sugrịžimu atstumu. Jos turètų atspindèti tiek fliuvioglacialinių, tiek moreninių ledyninių nuogulų ${ }^{87} \mathrm{Sr} /{ }^{86} \mathrm{Sr}$ reikšmes, kurios gali skirtis dèl fliuvioglacialiniuose smèliuose ir žvyruose lengviau negu moreniniame priemolyje išplaunamų karbonatų. Plati tirtų gyvūnų rūšių ịvairovè (bebras, elnias, ožka, avis/ožka, kiaulè) turèjo prisidèti prie stroncio izotopinio fono patikimumo (1 lent.). 


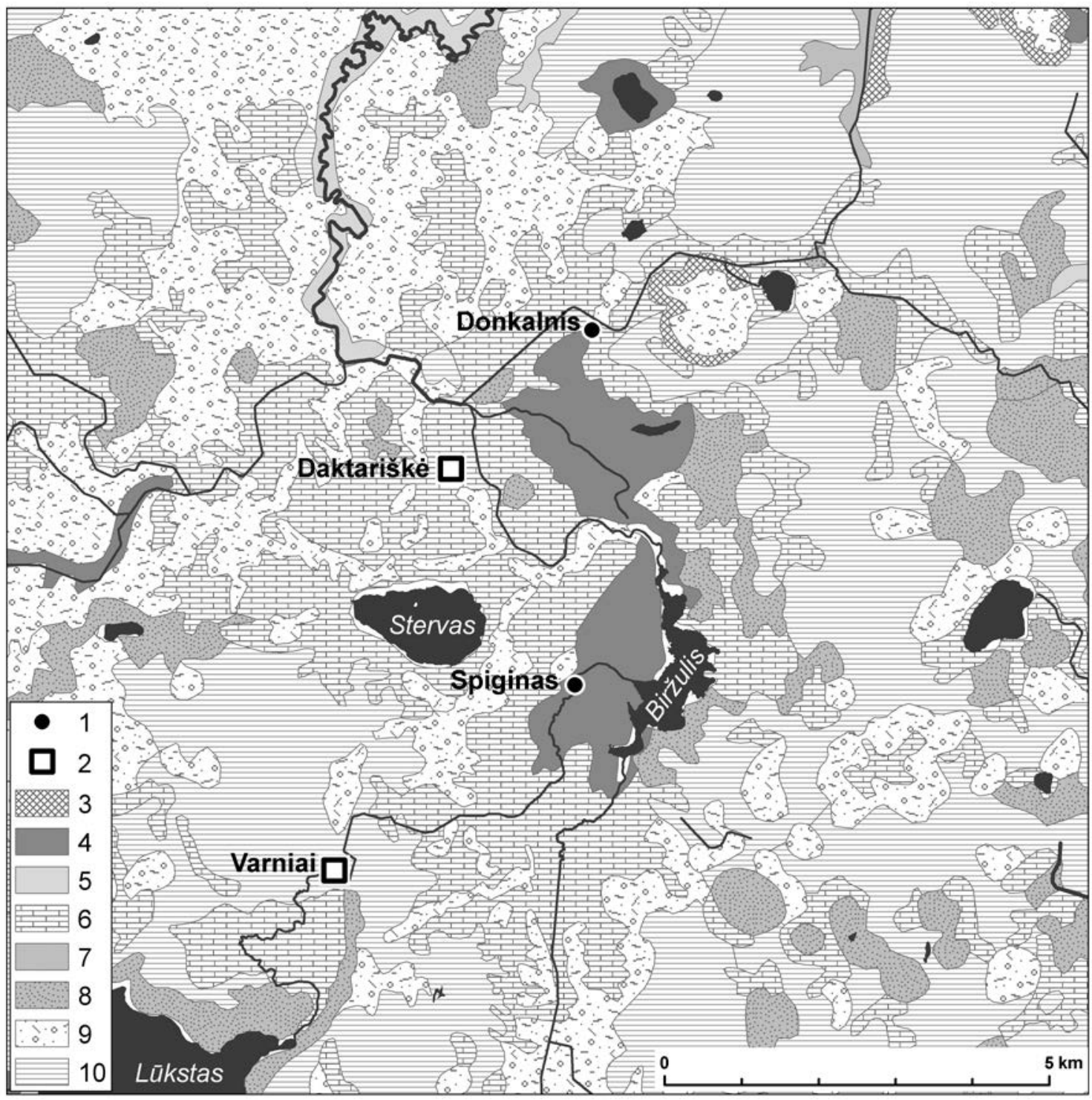

2 pav. Biržulio ežero apylinkių geologinis kvartero žemėlapis 1:200 000 (pagal Lietuvos geologijos tarnyba 2021). 1 - tirti žmonių dantys, 2 - tirti gyvūnų dantys, 3 - holoceno deliuvis, 4 - holoceno limninès nuosėdos, 5 - holoceno aliuvis, 6 - holoceno pelkių nuogulos, 7 - vèlyvojo pleistoceno aliuvis, 8 - vèlyvojo pleistoceno limnoglacialinès nuogulos, 9 - vèlyvojo pleistoceno fliuvioglacialinès nuogulos, 10 - vèlyvojo pleistoceno moreninès nuogulos. G. Piličiausko bréž.

Fig. 2. Quaternary geological map 1:200 000 of the Lake Biržulis region according to Lietuvos geologijos tarnyba 2021. 1 - analysed human teeth, 2 - analysed animal teeth, 3 - Holocene colluvium, 4 - Holocene limnic sediments, 5 - Holocene alluvium, 6 - Holocene bog sediments, 7 - Late Pleistocene alluvium, 8 - Late Pleistocene glaciolacustrine sediments, 9 - Late Pleistocene glaciofluvial sediments, 10 - Late Pleistocene moraine sediments. Drawing by G. Piličiauskas 


\begin{tabular}{|c|c|c|c|c|c|c|}
\hline $\begin{array}{l}\text { Eil. } \\
\text { nr. }\end{array}$ & Gyvenvietè & Tyrèjas, tyrimų metai & Datavimas & Rūšis & ${ }^{87} \mathrm{Sr} /{ }^{86} \mathrm{Sr}$ & SD \\
\hline 1 & Daktariškè 5 & Piličiauskas 2016 & $\begin{array}{l}\text { subneolitas, ankstyvasis } \\
\text { bronzos amžius }\end{array}$ & bebras & 0,713292 & 0,000013 \\
\hline 2 & Daktariškè 5 & Piličiauskas, 2016 & $\begin{array}{l}\text { subneolitas - ankstyvasis } \\
\text { bronzos amžius }\end{array}$ & bebras & 0,714841 & 0,000013 \\
\hline 3 & Daktariškè 5 & Piličiauskas, 2016 & ankstyvasis bronzos amžius & ožka & 0,71425 & 0,000013 \\
\hline 4 & Daktariškė 5 & Piličiauskas, 2016 & ankstyvasis bronzos amžius & avis/ožka & 0,713485 & 0,000013 \\
\hline 5 & Daktariškè 5 & Piličiauskas, 2016 & $\begin{array}{l}\text { subneolitas - ankstyvasis } \\
\text { bronzos amžius }\end{array}$ & elnias & 0,71495 & 0,000013 \\
\hline 6 & Varniai, Daukanto g. 8 & Kontrimas, 2013 & ankstyvieji naujieji laikai & kiaulè & 0,714592 & 0,000013 \\
\hline 7 & Varniai, Daukanto g. 8 & Kontrimas, 2013 & ankstyvieji naujieji laikai & kiaulè & 0,716614 & 0,000013 \\
\hline 8 & Varniai, Daukanto g. 8 & Kontrimas, 2013 & ankstyvieji naujieji laikai & kiaulè & $0,7155^{*}$ & $0,0002^{*}$ \\
\hline 9 & Varniai, Daukanto g. 8 & Kontrimas, 2013 & ankstyvieji naujieji laikai & avis/ožka & $0,7138^{\star}$ & $0,0005^{\star}$ \\
\hline
\end{tabular}

1 lent. Tirtų gyvūnų dantų iš Daktariškès 5 gyvenvietès ir Varnių miestelio sąrašas ir ${ }^{87} \mathrm{Sr} /{ }^{86} \mathrm{Sr}$ matavimų rezultatai.

$$
\begin{gathered}
\text { * - LA-MC-ICP-MS matavimai, } \\
\text { kiti - ID-TIMS matavimai }
\end{gathered}
$$

Table $1 .{ }^{87} \mathrm{Sr} /{ }^{86} \mathrm{Sr}$ ratios of analysed animal teeth from the sites of Daktariške 5 and Varniai.

* denotes analyses by LA-MC-ICP-MS,

other are by ID-TIMS

Tokiu būdu iš 9 gyvūnų apskaičiuotas biologiškai prieinamo stroncio izotopų fonas Biržulio ežero regione yra 0,7146 $\pm 0,0021$ (2 SD), arba $0,7125-0,7167$.

\section{DONKALNIO IR SPIGINO ŽMONIŲ KILME் IR MOBILUMAS}

Trylikai Donkalnio ir Spigino žmonių dantų buvo atlikti $193{ }^{87} \mathrm{Sr} /{ }^{86} \mathrm{Sr}$ matavimai taikant LA-MCICP-MS. Vienam dančiui daryta 10-20 matavimo ipjovų (linijų), vidutiniškai - po 15. Visi rezultatai, iskaitant 2 SD paklaidas, pateikiami suapvalinti iki 4 skaitmens po kablelio (2 lent.). Pagal šiuos matavimus visiems individams nubraižytos ${ }^{87} \mathrm{Sr} /{ }^{86} \mathrm{Sr}$ santykio vidinès variacijos kreivès, atspindinčios tirto danties emalio formavimosi chronologiją (3 pav.). Toliau jos naudotos tiek nevietiniams individams identifikuoti, tiek atskirų individų mobilumo pobūdžiui įvertinti.

\begin{tabular}{|l|l|l|l|c|}
\hline Kapinynas & Kapas & \multicolumn{1}{|c|}{ Linija } & \multicolumn{1}{|c|}{${ }^{87} \mathbf{S r}{ }^{86} \mathbf{S r}$} & 2SD \\
\hline Donkalnis & 1 & 1 & 0,7133 & 0,0005 \\
\hline Donkalnis & 1 & 2 & 0,7145 & 0,0006 \\
\hline Donkalnis & 1 & 3 & 0,7145 & 0,0006 \\
\hline Donkalnis & 1 & 4 & 0,7118 & 0,0005 \\
\hline Donkalnis & 1 & 5 & 0,7126 & 0,0006 \\
\hline Donkalnis & 1 & 6 & 0,7134 & 0,0007 \\
\hline Donkalnis & 1 & 7 & 0,7133 & 0,0006 \\
\hline Donkalnis & 1 & 8 & 0,7132 & 0,0006 \\
\hline Donkalnis & 1 & 9 & 0,7139 & 0,0006 \\
\hline Donkalnis & 1 & 10 & 0,7132 & 0,0005 \\
\hline Donkalnis & 1 & 11 & 0,7131 & 0,0005 \\
\hline Donkalnis & 1 & 12 & 0,7147 & 0,0006 \\
\hline Donkalnis & 1 & 13 & 0,7144 & 0,0006 \\
\hline Donkalnis & 1 & 14 & 0,7154 & 0,0005 \\
\hline Donkalnis & 1 & 15 & 0,7153 & 0,0006 \\
\hline Donkalnis & 1 & 16 & 0,7147 & 0,0005 \\
\hline Donkalnis & 2 & 1 & 0,7186 & 0,0005 \\
\hline Donkalnis & 2 & 2 & 0,7199 & 0,0005 \\
\hline Donkalnis & 2 & 3 & 0,7189 & 0,0005 \\
\hline & & & & \\
\hline
\end{tabular}




\begin{tabular}{|l|l|l|l|c|}
\hline Kapinynas & Kapas & \multicolumn{1}{|l|}{ Linija } & \multicolumn{1}{|c|}{${ }^{87} \mathbf{S r}^{\mathbf{8}}{ }^{\mathbf{S r}}$} & 2SD \\
\hline Donkalnis & 2 & 4 & 0,7202 & 0,0007 \\
\hline Donkalnis & 2 & 5 & 0,7163 & 0,0005 \\
\hline Donkalnis & 2 & 6 & 0,7164 & 0,0004 \\
\hline Donkalnis & 2 & 7 & 0,7174 & 0,0005 \\
\hline Donkalnis & 2 & 8 & 0,7170 & 0,0004 \\
\hline Donkalnis & 2 & 9 & 0,7183 & 0,0006 \\
\hline Donkalnis & 2 & 10 & 0,7193 & 0,0008 \\
\hline Donkalnis & 2 & 11 & 0,7190 & 0,0005 \\
\hline Donkalnis & 2 & 12 & 0,7170 & 0,0003 \\
\hline Donkalnis & 2 & 13 & 0,7162 & 0,0003 \\
\hline Donkalnis & 2 & 14 & 0,7159 & 0,0003 \\
\hline Donkalnis & 2 & 15 & 0,7156 & 0,0002 \\
\hline Donkalnis & 2 & 16 & 0,7128 & 0,0002 \\
\hline Donkalnis & 3 & 1 & 0,7126 & 0,0005 \\
\hline Donkalnis & 3 & 2 & 0,7126 & 0,0005 \\
\hline Donkalnis & 3 & 3 & 0,7120 & 0,0005 \\
\hline Donkalnis & 3 & 4 & 0,7122 & 0,0005 \\
\hline Donkalnis & 3 & 5 & 0,7122 & 0,0006 \\
\hline Donkalnis & 3 & 6 & 0,7116 & 0,0006 \\
\hline Donkalnis & 3 & 7 & 0,7121 & 0,0006 \\
\hline Donkalnis & 3 & 8 & 0,7112 & 0,0005 \\
\hline Donkalnis & 3 & 9 & 0,7119 & 0,0004 \\
\hline Donkalnis & 3 & 10 & 0,7113 & 0,0004 \\
\hline Donkalnis & 3 & 11 & 0,7117 & 0,0005 \\
\hline Donkalnis & 3 & 12 & 0,7121 & 0,0004 \\
\hline Donkalnis & 3 & 13 & 0,7116 & 0,0004 \\
\hline Donkalnis & 3 & 14 & 0,7113 & 0,0004 \\
\hline Donkalnis & 3 & 15 & 0,7121 & 0,0004 \\
\hline Donkalnis & 3 & 16 & 0,7117 & 0,0004 \\
\hline Donkalnis & 5 & 1 & 0,7138 & 0,0006 \\
\hline Donkalnis & 5 & 2 & 0,7136 & 0,0005 \\
\hline Donkalnis & 5 & 3 & 0,7121 & 0,0006 \\
\hline Donkalnis & 5 & 4 & 0,7116 & 0,0005 \\
\hline Donkalnis & 5 & 5 & 0,7124 & 0,0006 \\
\hline Donkalnis & 5 & 6 & 0,7120 & 0,0008 \\
\hline Donkalnis & 5 & 7 & 0,7116 & 0,0005 \\
\hline Donkalnis & 5 & 8 & 0,7118 & 0,0009 \\
\hline Donkalnis & 5 & 9 & 0,7119 & 0,0006 \\
\hline Donkalnis & 5 & 1071118 & 0,0006 \\
\hline Donkalnis & 5 & 115 & 0,0007 \\
\hline Donkalnis & 5 & 120005 \\
\hline
\end{tabular}

\begin{tabular}{|l|l|l|l|c|}
\hline Kapinynas & Kapas & \multicolumn{1}{|c|}{ Linija } & \multicolumn{1}{|c|}{${ }^{87} \mathbf{S r}^{86} \mathbf{S r}$} & 2SD \\
\hline Donkalnis & 5 & 13 & 0,7114 & 0,0006 \\
\hline Donkalnis & 5 & 14 & 0,7106 & 0,0006 \\
\hline Donkalnis & 5 & 15 & 0,7111 & 0,0005 \\
\hline Donkalnis & 5 & 16 & 0,7120 & 0,0005 \\
\hline Donkalnis & 6 & 1 & 0,7155 & 0,0005 \\
\hline Donkalnis & 6 & 2 & 0,7163 & 0,0004 \\
\hline Donkalnis & 6 & 3 & 0,7142 & 0,0005 \\
\hline Donkalnis & 6 & 4 & 0,7148 & 0,0005 \\
\hline Donkalnis & 6 & 5 & 0,7162 & 0,0005 \\
\hline Donkalnis & 6 & 6 & 0,7158 & 0,0005 \\
\hline Donkalnis & 6 & 7 & 0,7150 & 0,0005 \\
\hline Donkalnis & 6 & 8 & 0,7142 & 0,0005 \\
\hline Donkalnis & 6 & 9 & 0,7135 & 0,0004 \\
\hline Donkalnis & 7 & 1 & 0,7196 & 0,0006 \\
\hline Donkalnis & 7 & 2 & 0,7197 & 0,0005 \\
\hline Donkalnis & 7 & 3 & 0,7207 & 0,0005 \\
\hline Donkalnis & 7 & 4 & 0,7190 & 0,0006 \\
\hline Donkalnis & 7 & 5 & 0,7195 & 0,0006 \\
\hline Donkalnis & 7 & 6 & 0,7192 & 0,0005 \\
\hline Donkalnis & 7 & 7 & 0,7178 & 0,0005 \\
\hline Donkalnis & 7 & 8 & 0,7144 & 0,0005 \\
\hline Donkalnis & 7 & 9 & 0,7138 & 0,0005 \\
\hline Donkalnis & 7 & 10 & 0,7154 & 0,0005 \\
\hline Donkalnis & 7 & 11 & 0,7156 & 0,0005 \\
\hline Donkalnis & 7 & 12 & 0,7159 & 0,0005 \\
\hline Donkalnis & 7 & 13 & 0,7150 & 0,0004 \\
\hline Donkalnis & 7 & 14 & 0,7156 & 0,0005 \\
\hline Donkalnis & 7 & 15 & 0,7149 & 0,0004 \\
\hline Donkalnis & I & 1 & 0,7155 & 0,0006 \\
\hline Donkalnis & I & 2 & 0,7154 & 0,0006 \\
\hline Donkalnis & I & 3 & 0,7145 & 0,0006 \\
\hline Donkalnis & I & 4 & 0,7150 & 0,0007 \\
\hline Donkalnis & I & 5 & 0,7142 & 0,0005 \\
\hline Donkalnis & I & 6 & 0,7163 & 0,0005 \\
\hline Donkalnis & I & 7 & 0,7160 & 0,0007 \\
\hline Donkalnis & I & 8 & 0,7170 & 0,0007 \\
\hline Donkalnis & I & 9 & 0,7175 & 0,0007 \\
\hline Donkalnis & I & 10 & 0,7158 & 0,0006 \\
\hline Donkalnis & I & 11 & 0,7164 & 0,0007 \\
\hline Donkalnis & I & 127155 & 0,0005 \\
\hline Donkalnis & I & 0,7156 & 0,0005 \\
\hline
\end{tabular}




\begin{tabular}{|l|l|l|l|c|}
\hline Kapinynas & Kapas & \multicolumn{1}{|c|}{ Linija } & \multicolumn{1}{|c|}{${ }^{87} \mathbf{S r}{ }^{86} \mathbf{S r}$} & 2SD \\
\hline Donkalnis & I & 14 & 0,7146 & 0,0004 \\
\hline Donkalnis & III & 1 & 0,7162 & 0,0006 \\
\hline Donkalnis & III & 2 & 0,7157 & 0,0007 \\
\hline Donkalnis & III & 3 & 0,7149 & 0,0005 \\
\hline Donkalnis & III & 4 & 0,7156 & 0,0005 \\
\hline Donkalnis & III & 5 & 0,7156 & 0,0006 \\
\hline Donkalnis & III & 6 & 0,7155 & 0,0007 \\
\hline Donkalnis & III & 7 & 0,7146 & 0,0007 \\
\hline Donkalnis & III & 8 & 0,7156 & 0,0006 \\
\hline Donkalnis & III & 9 & 0,7155 & 0,0007 \\
\hline Donkalnis & III & 10 & 0,7138 & 0,0005 \\
\hline Donkalnis & III & 11 & 0,7136 & 0,0005 \\
\hline Donkalnis & III & 12 & 0,7149 & 0,0005 \\
\hline Donkalnis & IV & 1 & 0,7167 & 0,0006 \\
\hline Donkalnis & IV & 2 & 0,7165 & 0,0006 \\
\hline Donkalnis & IV & 3 & 0,7154 & 0,0007 \\
\hline Donkalnis & IV & 4 & 0,7160 & 0,0006 \\
\hline Donkalnis & IV & 5 & 0,7164 & 0,0006 \\
\hline Donkalnis & IV & 6 & 0,7157 & 0,0006 \\
\hline Donkalnis & IV & 7 & 0,7154 & 0,0006 \\
\hline Donkalnis & IV & 8 & 0,7162 & 0,0007 \\
\hline Donkalnis & IV & 9 & 0,7160 & 0,0007 \\
\hline Donkalnis & IV & 10 & 0,7148 & 0,0006 \\
\hline Donkalnis & IV & 11 & 0,7143 & 0,0006 \\
\hline Donkalnis & IV & 12 & 0,7147 & 0,0007 \\
\hline Donkalnis & IV & 13 & 0,7149 & 0,0006 \\
\hline Donkalnis & IV & 14 & 0,7140 & 0,0006 \\
\hline Donkalnis & IV & 15 & 0,7139 & 0,0007 \\
\hline Donkalnis & IV & 16 & 0,7150 & 0,0009 \\
\hline Donkalnis & IV & 17 & 0,7146 & 0,0006 \\
\hline Donkalnis & IV & 18 & 0,7142 & 0,0005 \\
\hline Donkalnis & IV & 19 & 0,7148 & 0,0005 \\
\hline Donkalnis & IV & 20 & 0,7155 & 0,0005 \\
\hline Donkalnis & V & 1 & 0,7144 & 0,0006 \\
\hline Donkalnis & V & 2 & 0,7136 & 0,0006 \\
\hline Donkalnis & V & 3 & 0,7134 & 0,0006 \\
\hline Donkalnis & V & 4 & 0,7141 & 0,0006 \\
\hline Donkalnis & V & 5 & 0,7141 & 0,0005 \\
\hline Donkalnis & V & 6 & 0,7136 & 0,0006 \\
\hline Donkalnis & V & 7137 & 0,0005 \\
\hline
\end{tabular}

\begin{tabular}{|l|l|l|l|l|}
\hline Kapinynas & Kapas & \multicolumn{1}{|c|}{ inija } & \multicolumn{1}{|c|}{${ }^{87} \mathbf{~}^{86} \mathbf{S r}$} & 2SD \\
\hline Donkalnis & V & 8 & 0,7138 & 0,0005 \\
\hline Donkalnis & V & 9 & 0,7152 & 0,0005 \\
\hline Donkalnis & V & 10 & 0,7143 & 0,0005 \\
\hline Donkalnis & V & 11 & 0,7137 & 0,0005 \\
\hline Donkalnis & V & 12 & 0,7134 & 0,0005 \\
\hline Donkalnis & V & 13 & 0,7137 & 0,0004 \\
\hline Donkalnis & V & 14 & 0,7146 & 0,0005 \\
\hline Donkalnis & V & 15 & 0,7138 & 0,0005 \\
\hline Donkalnis & VI & 1 & 0,7237 & 0,0012 \\
\hline Donkalnis & VI & 2 & 0,7262 & 0,0017 \\
\hline Donkalnis & VI & 3 & 0,7213 & 0,0008 \\
\hline Donkalnis & VI & 4 & 0,7210 & 0,0009 \\
\hline Donkalnis & VI & 5 & 0,7217 & 0,001 \\
\hline Donkalnis & VI & 6 & 0,7230 & 0,0008 \\
\hline Donkalnis & VI & 7 & 0,7193 & 0,0006 \\
\hline Donkalnis & VI & 8 & 0,7204 & 0,0008 \\
\hline Donkalnis & VI & 9 & 0,7201 & 0,0008 \\
\hline Donkalnis & VI & 10 & 0,7205 & 0,0006 \\
\hline Donkalnis & VI & 11 & 0,7202 & 0,0007 \\
\hline Donkalnis & VI & 12 & 0,7199 & 0,0009 \\
\hline Donkalnis & VI & 13 & 0,7204 & 0,0006 \\
\hline Donkalnis & VI & 14 & 0,7177 & 0,0006 \\
\hline Donkalnis & VI & 15 & 0,7186 & 0,0006 \\
\hline Donkalnis & VI & 16 & 0,7210 & 0,0008 \\
\hline Donkalnis & VI & 17 & 0,7202 & 0,0007 \\
\hline Donkalnis & VI & 18 & 0,7211 & 0,0009 \\
\hline Spiginas & 2 & 1 & 0,7168 & 0,0005 \\
\hline Spiginas & 2 & 2 & 0,7170 & 0,0006 \\
\hline Spiginas & 2 & 3 & 0,7160 & 0,0005 \\
\hline Spiginas & 2 & 4 & 0,7158 & 0,0005 \\
\hline Spiginas & 2 & 5 & 0,7151 & 0,0005 \\
\hline Spiginas & 2 & 6 & 0,7153 & 0,0004 \\
\hline Spiginas & 2 & 7 & 0,7153 & 0,0004 \\
\hline Spiginas & 2 & 8 & 0,7150 & 0,0004 \\
\hline Spiginas & 2 & 9 & 0,7151 & 0,0004 \\
\hline Spiginas & 2 & 10 & 0,7147 & 0,0004 \\
\hline Spiginas & 4 & 1 & 0,7134 & 0,0006 \\
\hline Spiginas & 4 & 2 & 0,7137 & 0,0005 \\
\hline Spiginas & 4 & 3 & 0,7122 & 0,0005 \\
\hline Spiginas & 4 & 4 & & 0,0005 \\
\hline & & & & \\
\hline
\end{tabular}




\begin{tabular}{|l|l|l|l|c|}
\hline Kapinynas & Kapas & \multicolumn{1}{|c|}{ Linija } & \multicolumn{1}{|c|}{${ }^{87} \mathbf{S r}{ }^{86} \mathbf{S r}$} & 2SD \\
\hline Spiginas & 4 & 5 & 0,7132 & 0,0006 \\
\hline Spiginas & 4 & 6 & 0,7132 & 0,0005 \\
\hline Spiginas & 4 & 7 & 0,7125 & 0,0004 \\
\hline Spiginas & 4 & 8 & 0,7133 & 0,0005 \\
\hline Spiginas & 4 & 9 & 0,7127 & 0,0004 \\
\hline Spiginas & 4 & 10 & 0,7130 & 0,0005 \\
\hline
\end{tabular}

\begin{tabular}{|l|l|l|l|c|}
\hline Kapinynas & Kapas & \multicolumn{1}{|c|}{ Linija } & \multicolumn{1}{|c|}{${ }^{87} \mathbf{S r} /{ }^{86} \mathbf{S r}$} & 2SD \\
\hline Spiginas & 4 & 11 & 0,7129 & 0,0004 \\
\hline Spiginas & 4 & 12 & 0,7127 & 0,0004 \\
\hline Spiginas & 4 & 13 & 0,7130 & 0,0005 \\
\hline Spiginas & 4 & 14 & 0,7138 & 0,0006 \\
\hline Spiginas & 4 & 15 & 0,7156 & 0,0007 \\
\hline Spiginas & 4 & 16 & 0,7132 & 0,0005 \\
\hline
\end{tabular}

2 lent. Tirtų žmonių iš Donkalnio ir Spigino kapinynų dantų emalio ${ }^{87} \mathrm{Sr} /{ }^{86} \mathrm{Sr}$ matavimų rezultatai

Table $2 .{ }^{87} \mathrm{Sr} /{ }^{86} \mathrm{Sr}$ ratios of analysed human teeth from the burial grounds of Donkalnis and Spiginas

\begin{tabular}{|c|c|c|c|c|c|c|c|c|c|}
\hline $\begin{array}{l}\text { Eil. } \\
\text { nr. }\end{array}$ & Kapinynas & Kapas & Lytis & Amžius & Dantis & Datavimas & $\begin{array}{l}{ }^{87} \mathrm{Sr} /{ }^{86} \mathrm{Sr} \\
\text { vidurkis }\end{array}$ & SD & Interpretacija \\
\hline 1 & Donkalnis & 1 & $\mathrm{~m}$ & $18-20$ & M1 & subneolitas & 0,7138 & 0,001 & $\begin{array}{l}\text { pusiau vie- } \\
\text { tinis }\end{array}$ \\
\hline 2 & Donkalnis & 2 & $\mathrm{v}$ & $20-25$ & M1 & mezolitas & 0,7174 & 0,0019 & nevietinis \\
\hline 3 & Donkalnis & 3 & $\mathrm{~m}$ & $25-30$ & M3 & subneolitas & 0,7119 & 0,0004 & nevietinis \\
\hline 4 & Donkalnis & 5 & $?$ & $5-9$ & M1 & mezolitas & 0,7119 & 0,0009 & $\begin{array}{l}\text { pusiau vie- } \\
\text { tinis }\end{array}$ \\
\hline 5 & Donkalnis & 6 & $\mathrm{~m}$ & $>30$ & M2 & subneolitas & 0,7151 & 0,001 & vietinis \\
\hline 6 & Donkalnis & 7 & $\mathrm{v}$ & $\sim 50$ & $\mathrm{P} 2$ & subneolitas & 0,7171 & 0,0023 & nevietinis \\
\hline 7 & Donkalnis & suardytas I & $\mathrm{v}$ & $>30$ & M2 & subneolitas & 0,7157 & 0,0009 & $\begin{array}{l}\text { pusiau vie- } \\
\text { tinis }\end{array}$ \\
\hline 8 & Donkalnis & suardytas III & $\mathrm{v}$ & $20-30$ & M1 & subneolitas & 0,7151 & 0,0008 & vietinis \\
\hline 9 & Donkalnis & suardytas IV & $?$ & suaugęs & M1 & subneolitas & 0,7153 & 0,0008 & vietinis \\
\hline 10 & Donkalnis & suardytas V & $?$ & $20-30$ & M1 & mezolitas & 0,7139 & 0,0005 & vietinis \\
\hline 11 & Donkalnis & suardytas VI & $?$ & $6-8$ & M1 & subneolitas & 0,7209 & 0,0019 & nevietinis \\
\hline 12 & Spiginas & 2 & $\mathrm{v}$ & $50-55$ & M2 & neolitas & 0,7156 & 0,0008 & vietinis \\
\hline 13 & Spiginas & 4 & $\mathrm{~m}$ & $30-35$ & M1 & mezolitas & 0,7132 & 0,0008 & vietinis \\
\hline
\end{tabular}

3 lent. Tirtų žmonių iš Donkalnio ir Spigino kapinynų ${ }^{87} \mathrm{Sr} /{ }^{86} \mathrm{Sr}$ vidurkiai ir interpretacija

Table 3. Mean ${ }^{87} \mathrm{Sr} /{ }^{86} \mathrm{Sr}$ ratios of analysed human teeth from the burial grounds of Donkalnis and Spiginas, and interpretation 
Pagal danties vidinès ${ }^{87} \mathrm{Sr} /{ }^{86} \mathrm{Sr}$ variacijos kreives ir jų santykị su regiono biosferinio ${ }^{87} \mathrm{Sr} /{ }^{86} \mathrm{Sr}$ fonu tirti individai iš Donkalnio ir Spigino kapinynų buvo suskirstyti į 3 grupes: vietinius, nevietinius ir pusiau vietinius (3 lent.). Vietiniais vadinami individai, $\mathrm{ku}$ rių vidinè ${ }^{87} \mathrm{Sr} /{ }^{86} \mathrm{Sr}$ santykio variacija neviršija regiono fono $(0,7125-0,7167)$. Tikètina, jie gimė Biržulio ežero regione ir praleido čia bent kelerius metus iš jo neišvykdami. Vis dèlto iš ${ }^{87} \mathrm{Sr} /{ }^{86} \mathrm{Sr}$ matavimų kitose Lietuvos vietose žinome, kad daugelio Lietuvos regionų ${ }^{87} \mathrm{Sr} /{ }^{86} \mathrm{Sr}$ fonai yra panašūs ir stipriai persidengia (Piličiauskas et al., rengiama), tad visuomet išlieka tikimybè, kad kai kurie individai su vietinėmis ${ }^{87} \mathrm{Sr} /{ }^{86} \mathrm{Sr}$ vertemis iš tiesų yra nevietiniai. Nevietiniais individais laikysime tuos, kurių visa ${ }^{87} \mathrm{Sr} /{ }^{86} \mathrm{Sr}$ santykio kreivè arba bent pirmieji matavimai yra už regiono fono $(0,7125-0,7167)$ ribų. Šie turèjo gimti kažkur toliau nuo Biržulio. Pusiau vietiniais laikysime tuos, kurių ${ }^{87} \mathrm{Sr} /{ }^{86} \mathrm{Sr}$ kreivès pradžioje yra tarp Biržulio regiono fono $(0,7125-0,7167)$ ribų, tačiau vèlesnị danties emalio formavimosi metą atitinkančiuose matavimuose jau išeina už šių ribų. Tokie individai greičiausiai gimè kažkur prie Biržulio, vèliau išvyko ir sugrịžo. Be to, neatmestina galimybè, kad jie gimé ne prie Biržulio, o kitame regione, kuriame stroncio fonas panašus, o Biržulị iš ten pasiekè prieš tai pagyvenę kitokio ${ }^{87} \mathrm{Sr} /{ }^{86} \mathrm{Sr}$ fono aplinkoje.

Donkalnio ir Spigino žmonès pasižymi labai ivvairia ${ }^{87} \mathrm{Sr} /{ }^{86} \mathrm{Sr}$ variacija viename dantyje standartinei deviacijai esant nuo 0,0004 (Donkalnio kapas 3) iki 0,0023 (Donkalnio kapas 7). Daugumos individų (7 iš 13) ${ }^{87} \mathrm{Sr} /{ }^{86} \mathrm{Sr}$ SD yra 0,0008-0,0009 (4 pav.). Tokią vidinę variaciją vadinsime vidutine. Dviejų individų vidinè variacija žema $(S D=0,0004-0,0005)$, trijų labai aukšta (SD = 0,0019-0,0023).

Vidine ${ }^{87} \mathrm{Sr} /{ }^{86} \mathrm{Sr}$ variacija rodo individo mobilumo laipsni. Sèsliai gyvenusių žvejų vidinè variacija turètų būti žema, nors tokia pati gali būti tų, kurių sezoninès gyvenvietės buvo vietovèse, kur stroncio radiogeniškumas panašus. Vidutinę vidinę variaciją turinčių individų ${ }^{87} \mathrm{Sr} /{ }^{86} \mathrm{Sr}$ kreivèse galima tikètis aptikti sezoninio mobilumo požymių. Tai turètų rodyti ${ }^{87} \mathrm{Sr} /{ }^{86} \mathrm{Sr}$ vidinès variacijos cikliškumas, sukuriamas individui pakartotinai judant tarp tų pačių vietovių, pasižyminčių nevienodu stroncio radiogeniškumu. Tačiau iš variacijos ciklų skaičiaus neįmanoma tiksliai nustatyti, kiek kartų per danties emalio formavimosi laikotarpi sezoniškai judantis individas pakeitė gyvenamąją vietą, nes stroncio izotopų analizè neleidžia identifikuoti persikèlimo tarp vietovių, kuriose biosferos stroncio radiogeniškumas yra vienodas. Ciklinę vidinę ${ }^{87} \mathrm{Sr} /{ }^{86} \mathrm{Sr}$ variaciją gali sukelti ir sezoniniai dietos pokyčiai, tačiau ne visuose regionuose. Sausumos ir vandens maisto produktuo$\mathrm{se}^{87} \mathrm{Sr} /{ }^{86} \mathrm{Sr}$ santykis gali reikšmingai skirtis, jeigu upès plukdo vandenị iš kito regiono, kur geologija kitokia, arba surenka gruntinị vandenị iš gilių geologinių sluoksnių (Bentley 2006). Vis dèlto Biržulio atveju tai neįmanoma, nes jis yra aukštumoje, ji vagoja tik nedidelių upių aukštupiai, neturintys gilių slènių.

Aukštą vidinę variaciją prie Biržulio turi nevietinès kilmès individai. Jų mobilumo pobūdị ir laipsnị prieš persikèlimą ir/arba po jo taip pat galima vertinti pagal ${ }^{87} \mathrm{Sr} /{ }^{86} \mathrm{Sr}$ vidinès variacijos kreives.

Toliau, remdamiesi aukščiau apibūdintais stroncio izotopų analizès duomenų interpretacijos principais, vidines visų tirtų Donkalnio ir Spigino žmonių ${ }^{87} \mathrm{Sr} /{ }^{86} \mathrm{Sr}$ variacijas aptarsime individualiai, atsižvelgdami ir ị kitokių tyrimų duomenis.

Pradèsime nuo Spigino kape 2 neolite palaidoto apie $50 \mathrm{~m}$. vyro. Tirtas nuolatinis krūminis dantis $\mathrm{M} 2$, $\operatorname{tad}{ }^{87} \mathrm{Sr} /{ }^{86} \mathrm{Sr}$ vidinès variacijos kreivè atitinka 3-6 gyvenimo metus (Massler et al. 1941; Reid, Dean 2006). Vaikysteje šis vyras mažiausiai vieną kartą keitè gyvenamąją vietą persikeldamas iš aplinkos, kurioje stroncis radiogeniškesnis $\left({ }^{87} \mathrm{Sr} /{ }^{86} \mathrm{Sr} \sim 0,717\right)$, $\mathfrak{t}$ aplinką, kuris mažiau radiogeniškas $\left({ }^{87} \mathrm{Sr} /{ }^{86} \mathrm{Sr} \sim 0,715\right)$, tačiau tai vyko Biržulio ežero apylinkių ${ }^{87} \mathrm{Sr} /{ }^{86} \mathrm{Sr}$ fono ribose $(0,7125-0,7167)$. Vidineje šio individo variacijoje nèra cikliškumo, tad negalime joje įžiūrèti sezoninès migracijos požymių (3 pav.). Tikètina, kad po persikèlimo jis gyveno gana sèsliai arba judejjo 


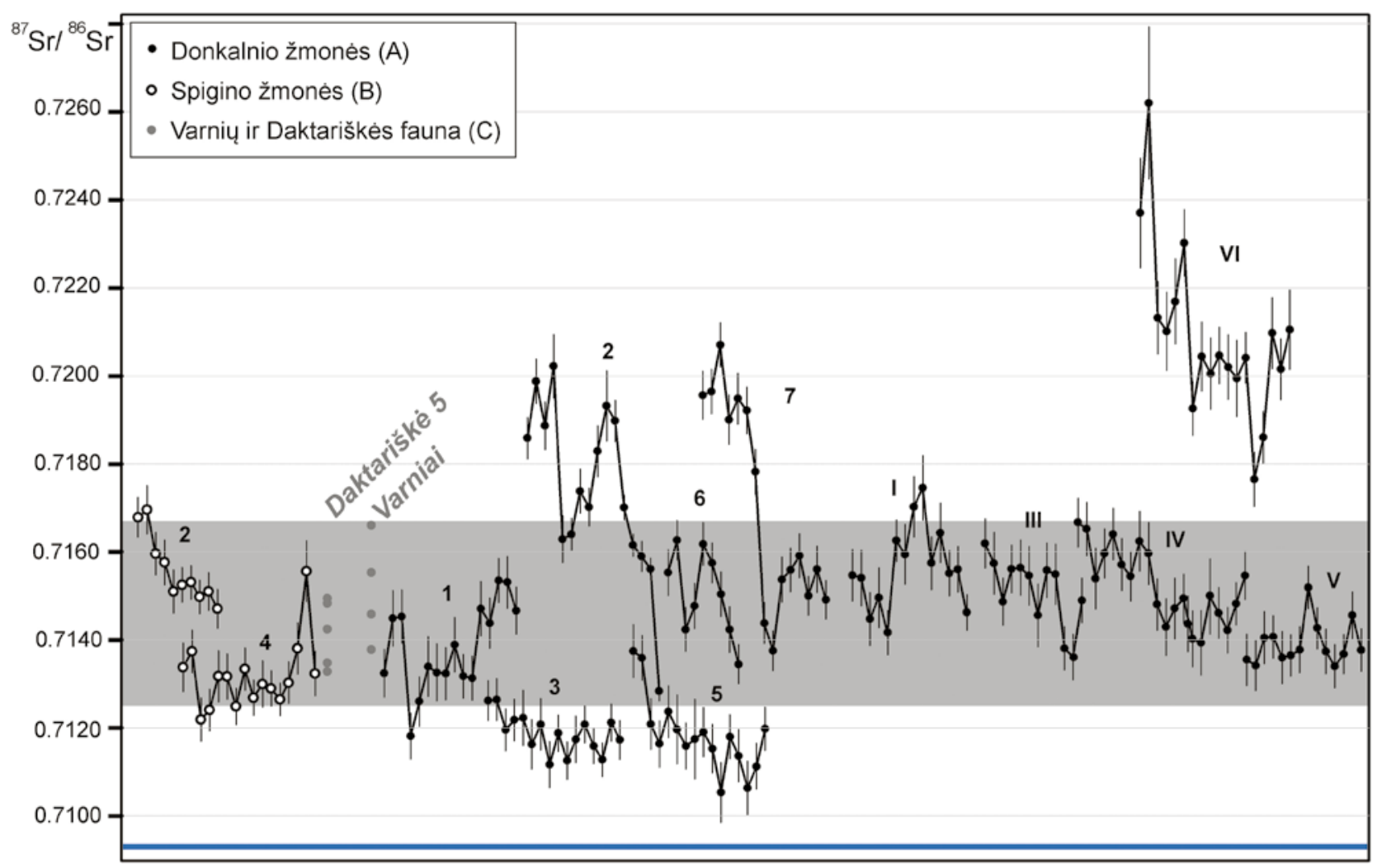

3 pav. Donkalnio ir Spigino mezolito-neolito gyventojų dantų emalio ${ }^{87} \mathrm{Sr}{ }^{86} \mathrm{Sr}$ vidinès variacijos kreivès gyvūnų iš Daktariškès 5 gyvenvietès ir Varnių miestelio ${ }^{87} \mathrm{Sr} /{ }^{86} \mathrm{Sr}$ fone (2 SD). Kiekvienam žmogaus danties matavimui pavaizduota ir 2 SD paklaida. Mèlyna linija grafiko apačioje vaizduoja Baltijos jūrai būdingą ${ }^{87} \mathrm{Sr} /{ }^{86} \mathrm{Sr}(0,7093$ pagal Andersson et al. 1992). G. Piličiausko brëž. Fig. 3. Intra-tooth ${ }^{87} \mathrm{Sr} /{ }^{86} \mathrm{Sr}$ ratio variation curves of the sampled Mesolithic-Neolithic individuals from the burial grounds of Donkalnis (A) and Spiginas (B). The baseline was established through the analyses of faunal remains from the sites of Daktariškes 5 and Varniai (C). These data are plotted at 2 SD as defined by the whiskers. The blue line at the bottom of the plot shows the ${ }^{87} \mathrm{Sr} /{ }^{86} \mathrm{Sr}$ ratio of Baltic seawater according to Andersson et al. (1992). Drawing by G. Piličiauskas

tarp vietovių, kur Sr... santykis panašus. Šio individo $\mathrm{C}$ ir $\mathrm{N}$ izotopų signalai skiriasi nuo mezolito ir subneolito žmonių ir rodo, kad šis neolito pabaigos gyventojas tikrai nebuvo žvejys, o maitinosi daugiausia sausuminiu maistu, galbūt naminių gyvulių produktais (1 pav.).

Spigino kape 4 mezolite palaidota $30-35 \mathrm{~m}$. moteris. Tirtas nuolatinis krūminis dantis M1, kurio emalis formuojasi 0-3 metais (Massler et al. 1941; Reid, Dean 2006). Šis individas irgi vertintinas kaip vietinis, tačiau vidinès ${ }^{87} \mathrm{Sr} /{ }^{86} \mathrm{Sr}$ variacijos kreiveje matomi du ${ }^{87} \mathrm{Sr} /{ }^{86} \mathrm{Sr}$ santykio kritimai, galbūt rodantys sezoninị mobilumą (3 pav.). Tai gana tipiškas mezolito ir subneolito individas, mobilus medžiotojas-rankiotojas, kurio baltymų dietoje vyravo gèlavandenès žuvys (1 pav.).

Donkalnio kape 1 subneolite palaidota apie 18$20 \mathrm{~m}$. moteris. Tirtas nuolatinis krūminis dantis M1, kurio emalis formuojasi 0-3 metais (Massler et al. 1941; Reid, Dean 2006). Vidinejje ${ }^{87} \mathrm{Sr} /{ }^{86} \mathrm{Sr}$ variacijos kreiveje matomi pasikartojantys ${ }^{87} \mathrm{Sr} /{ }^{86} \mathrm{Sr}$ santykio kritimai ir kilimai, iš kurių tik vienas matavimas išeina už vietinio ${ }^{87} \mathrm{Sr} /{ }^{86} \mathrm{Sr}$ fono ribų. Tokia variacija interpretuotina kaip sezoninio mobilumo, daugiausia - Biržulio ežero apylinkèse, požymis (3 pav.). 


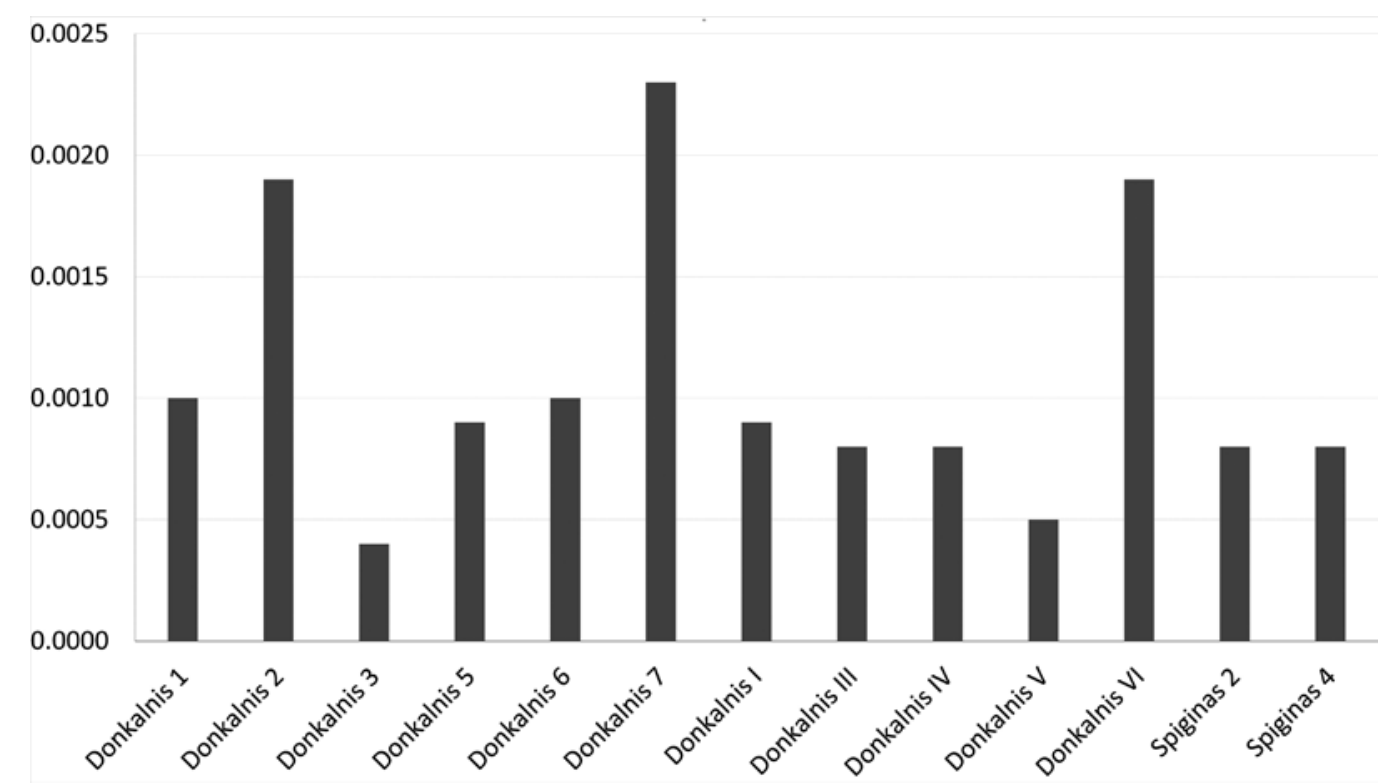

4 pav. Donkalnio ir Spigino žmonių ${ }^{87} \mathrm{Sr} r{ }^{86} \mathrm{Sr}$ matavimų viename dantyje standartinės deviacijos. G. Piličiausko brëž. Fig. 4. Standard deviations of the intra-tooth measurements of the individuals from Donkalnis and Spiginas. Drawing by G. Piličiauskas

Donkalnio kape 2 mezolite palaidotas apie 20$25 \mathrm{~m}$. vyras. Tirtas nuolatinis krūminis dantis M1, kurio emalis formuojasi 0-3 metais (Massler et al. 1941; Reid, Dean 2006). Tai neabejotinai nevietinis individas. Jis gimè regione, kurio ${ }^{87} \mathrm{Sr} /{ }^{86} \mathrm{Sr}$ fonas buvo apie 7,2. Ši vertè viršija bendrą Lietuvos biologiškai prieinamo stroncio foną (Piličiauskas et al., rengiama; Piličiauskienè et al., rengiama). Artimiausias regionas, kuriame buvo fiksuotos 0,72 ir aukštesnès ${ }^{87} \mathrm{Sr} /{ }^{86} \mathrm{Sr}$ vertès, yra pietų Suomija ir Karelija (5 pav.). Taigi, tikètina, kad šis vyras prie Biržulio atsikèlè dar ankstyvoje vaikysteje ir iš labai toli. Vidinès variacijos kreiveje matomas cikliškumas (3 pav.) gali būti interpretuojamas dvejopai. Arba kelionè truko ilgai, kelerius metus su tarpiniais punktais, pasižyminčiais ịvairaus radiogeniškumo stroncio fonais, arba individas pirmaisiais gyvenimo metais tarp gimtinès ir Biržulio judejo kelis kartus.

Donkalnio kape 3 subneolite palaidota apie 25$30 \mathrm{~m}$. moteris. Tirtas nuolatinis krūminis dantis M3, kurio emalis formuojasi 8-11 metais (Massler et al. 1941; Reid, Dean 2006). Šis individas išskirtinis tuo, kad vidine ${ }^{87} \mathrm{Sr} /{ }^{86} \mathrm{Sr}$ variacija yra pati žemiausia (SD = 0,0004) tarp Donkalnio ir Spigino žmonių (4 pav.). Pirmieji 2 matavimai iš anksčiausiai besiformuojančios emalio vietos ties danties viršūne davė vienodus rezultatus $-0,7126 \pm 0,0005$ (2SD) (3 pav.). Formaliai žiūrint jie patenka ị Biržulio ežero apylinkių biosferos ${ }^{87} \mathrm{Sr} /{ }^{86} \mathrm{Sr}$ foną $(0,7125-0,7167)$, tačiau yra žemesni už pačią žemiausią gyvūno ${ }^{87} \mathrm{Sr} /{ }^{86} \mathrm{Sr}$ vertę (Daktariškès 5 bebras, 0,7133). Kiti to paties danties matavimai jau davė žemesnes už Biržulio foną vertes, apie 0,711-0,712, kurių artimiausia vieta - tik pajūryje (Šventoji). Pajūryje biologiškai prieinamam stronciui didžiulę ịtaką dèl vadinamojo jūros purslų efekto daro jūros vanduo, kurio ${ }^{87} \mathrm{Sr} /{ }^{86} \mathrm{Sr}$ ties Gotlandu yra 0,7093 (Snoeck 2014; Alonzi et al. 2020; Andersson et al. 1992). Turint omenyje Daktariškejje surastus gintaro radinius ir todèl labai tikètinus glaudžius Biržulio ežero žmonių ryšius su pajūriu, 
Donkalnio 3 individo atvykimas iš pajūrio atrodo tikètinas. Tad Donkalnio 3 moteris greičiausiai gimè kažkur pajūryje, ten gyveno sèsliai - tai rodo itin maža vidinè ${ }^{87} \mathrm{Sr} /{ }^{86} \mathrm{Sr}$ variacija, o prie Biržulio atvyko būdama 12-20/25 m. Lagūninę-jūrinę dietą rodančių C ir $\mathrm{N}$ izotopų signalų kaule neišliko, nes, kaului persiformuojant, juos pakeitè mišri gèlavandenè dieta Biržulio regione (1 pav.).

Donkalnio kape 5 mezolite palaidoti kūdikis ir 5-9 m. vaikas, kurio ištirtas nuolatinis krūminis dantis M1. Jo emalis formuojasi 0-3 metais (Massler et al. 1941; Reid, Dean 2006), tad vidinès ${ }^{87} \mathrm{Sr} /{ }^{86} \mathrm{Sr}$ variacijos kreivè atitinka ši arba kiek trumpesni laikotarpi (3 pav.). Ji labai panaši ị kapo 3 moters. Pirmi 2 matavimai duoda ${ }^{87} \mathrm{Sr} /{ }^{86} \mathrm{Sr}$ vertes Biržulio ežero apylinkių fono ribose, tačiau vèlesnị danties emalio laikotarpi atitinkančios ${ }^{87} \mathrm{Sr} /{ }^{86} \mathrm{Sr}$ vertès jau yra už Biržulio fono ribų. Galimos dvi šio individo kilmès interpretacijos. Kadangi Biržulio ${ }^{87} \mathrm{Sr} /{ }^{86} \mathrm{Sr}$ fonas persidengia su Lietuvos pajūrio (Šventosios) fonu intervale 0,7125-0,7163 (Piličiauskas et al., rengiama), vaikas galejo gimti pajūryje ir persikelti prie Biržulio būdamas 4-5/9 m. Kita vertus, jis galejo gimti prie Biržulio, netrukus persikelti ị pajūrị, o tuomet, būdamas 3-5/9 m., grịžti ị Biržulị, kur netrukus ir numirè. Abiem atvejais prie jūros jis turèjo gyventi gana sėsliai, kaip ir subneolitinio kapo 3 moteris.

Donkalnio kape 6 subneolite palaidota $>30 \mathrm{~m}$. moteris. Tirtas nuolatinis krūminis dantis $\mathrm{M} 2$, tad ${ }^{87} \mathrm{Sr} /{ }^{86} \mathrm{Sr}$ vidinès variacijos kreivè rodo 3-6 metus (Massler et al. 1941; Reid, Dean 2006). Ji greičiausiai vietinès kilmès, ankstyvąją vaikystę irgi leido prie Biržulio, tačiau sezoninị mobilumą rodo vidutinè $(\mathrm{SD}=0,001)$ ir ciklinè (2 pakilimai ir 2 nusileidimai) vidine ${ }^{87} \mathrm{Sr} /{ }^{86} \mathrm{Sr}$ variacija Biržulio ežero apylinkių biosferos ${ }^{87} \mathrm{Sr} /{ }^{86} \mathrm{Sr}$ fono ribose (3 pav.).

Donkalnio kape 7 subneolite palaidotas apie $50 \mathrm{~m}$. vyras. Tirtas kaplys P2, kurio ${ }^{87} \mathrm{Sr} /{ }^{86} \mathrm{Sr}$ vidinès variacijos kreivè atitinka 2-6 gyvenimo metus (Massler et al. 1941; Reid, Dean 2006). Ji labai panaši į mezolitinio kapo 2 moters kreivę (3 pav.). ${ }^{87} \mathrm{Sr} /{ }^{86} \mathrm{Sr}$ santykis nuo aiškiai nevietinès reikšmès 0,72 emalio formavimosi viduryje staiga leidžiasi iki 0,715, t. y. ị Biržulio apylinkių ${ }^{87} \mathrm{Sr} /{ }^{86} \mathrm{Sr}$ fono diapazoną $(0,7125-0,7167)$. Taigi, galime manyti, kad asmuo gimè galbūt pietų Karelijoje arba Suomijoje, o prie Biržulio atvyko maždaug $4 \mathrm{~m}$., nors ir čia negyveno sèsliai. Šio individo maisto racione vyravo sausumos produktai, ne žuvys (1 pav.). Be to, šio individo genomas rodo $30 \%$ paveldimumo iš rytų medžiotojų-rinkejjų, ir tai yra didžiausia proporcija tarp visų genetiškai tirtų Donkalnio ir Spigino individų. Spigino 4 ir Donkalnio 1, 6 kapų žmonès, kuriuos stroncio izotopų tyrimas parode kaip gimusius prie Biržulio, genetiškai pasirodè esantys žymiai artimesni vakarų medžiotojams-rinkejjams, o su rytų medžiotojais-rinkejais yra siejama vos 0-10\% jų genomo (Mittnik et al. 2018, fig. 3). Tad genetiniai duomenys dar labiau sustiprina išvadą, kad Donkalnio 7 kapo vyras yra nevietinis, kilęs iš mišrios šeimos ir atvykęs iš toli.

Donkalnio suardytame kape I subneolite palaidotas $>30 \mathrm{~m}$. vyras. Tirtas nuolatinis krūminis dantis $\mathrm{M} 2$, $\operatorname{tad}{ }^{87} \mathrm{Sr} /{ }^{86} \mathrm{Sr}$ vidinès variacijos kreivè atitinka 3-6 gyvenimo metus (Massler et al. 1941; Reid, Dean 2006). Šiovietinio individo Sr... variacija yra vidutinè ir ciklinè vidinè (3 pav.), kuri rodo sezoninị mobilumą. Lygiai tą pačią interpretaciją galima taikyti suardytų kapų III-V mezolito ir subneolito individams. Nors kapo V individo ${ }^{87} \mathrm{Sr} /{ }^{86} \mathrm{Sr}$ vidinè variacija vertintina kaip maža $(S D=0,0004)$, tačiau ji didesnè už atskirų matavimų paklaidas (3 pav.), tad tikètina, kad ir šis individas gyvenvietes keitè sezoniškai.

Donkalnio suardytame kape VI subneolite palaidotas 6-8 m. vaikas, kurio ištirtas nuolatinis krūminis dantis M1. Jo emalis formuojasi 0-3 metais (Massler et al. 1941; Reid, Dean 2006), tad ši arba kiek trumpesnị laikotarpi rodo ${ }^{87} \mathrm{Sr} /{ }^{86} \mathrm{Sr}$ vidinès variacijos kreivè (3 pav.). Daugumos jo danties matavimo linijų rezultatai buvo daugiau kaip 0,72, t. y. aukštesni už visų tirtų Lietuvos regionų (Piličiauskas et al., rengiama; Piličiauskiené et al., rengiama). Kaip ir kapu 
2 ir 7 atvejais, labiausiai tikètinas kilmès regionas pietų Suomija ir Karelija su i paviršių išeinančiomis senomis prekambro uolienomis (5 pav.). Biržulio ežero apylinkes šis vaikas pasiekè 4-6/8-ais gyvenimo metais.

\section{DISKUSIJA IR IŠVADOS}

Vienas iš pirmųjų bandymų Lietuvos archeologijoje panaudoti stroncio izotopų analizę buvo rezultatyvus: nepalieka vietos skepticizmui ir skatina naujus stroncio izotopų tyrimus. Dèl tolimų migracijų priešistoreje, taip pat dèl reikšmingos biologiškai prieinamo stroncio ${ }^{87} \mathrm{Sr} /{ }^{86} \mathrm{Sr}$ santykio variacijos erdvejje metodas pasirodè esantis tinkamas identifikuoti pirmosios kartos migrantus net ir beveik ištisai ledynmečio nuogulomis padengtoje teritorijoje, kaip yra Lietuvoje. Donkalnio kapinyne 4 arba 5 žmonès iš 11 tirtų pasirodè esantys nevietiniai: 3 - galbūt gimę pietų Karelijoje arba Suomijoje, 1 arba 2 - Baltijos pajūryje.

LA-MC-ICP-MS metodas su daugybiniais vieno danties ${ }^{87} \mathrm{Sr} /{ }^{86} \mathrm{Sr}$ matavimais, nepaisant mažesnio jų tikslumo, pasirodè esantis pranašesnis už ID-TIMS, kuriam reikalingi didesni medžiagos kiekiai ir kuris matuoja ${ }^{87} \mathrm{Sr} /{ }^{86} \mathrm{Sr}$ santyki tik viename bendrajame danties emalio mėginyje. LA-MC-ICP-MS leidžia identifikuoti ir tuos nevietinius individus, kurie persikèlè ị savo mirties ar palaidojimo vietą praejus vos keliems mènesiams po jų gimimo (Donkalnio kapo 7 atvejis). Taikant ID-TIMS, jie greičiausiai būtų priskirti prie vietinių žmonių. Be to, LA-MC-ICPMS fiksuoja ${ }^{87} \mathrm{Sr} /{ }^{86} \mathrm{Sr}$ variaciją viename dantyje, kuri leidžia ịvertinti atskirų individų mobilumo laipsnị ir pobūdị, kurie tarp medžiotojų-rinkèjų pasirodè esantys itin nevienodi. Didelè arba vidutinè Biržulio ežero žmonių ${ }^{87} \mathrm{Sr} /{ }^{86} \mathrm{Sr}$ vidinè variacija rodo, kad mezolite ir subneolite net ir prie tokių didelių ir žuvingų vandens telkinių, kaip Biržulio ežeras, nebuvo pastovių, visus metus naudotų gyvenviečių. Žmonès buvo itin mobilūs, o sezoniškai kraustèsi ir žvejai. ${ }^{87} \mathrm{Sr} /{ }^{86} \mathrm{Sr}$ analizè rodo didesnị sèslumą tik pajūryje gyvenusių individų. LA-MC-ICP-MS metodu tiriant daugiau îvairių laikotarpių individų, būtų galima ịvertinti mobilumo laipsnị ir pobūdị bei jų pokyčius ne tik atskirų individų, bet ir skirtingose epochose, pavyzdžiui, atsirandant keramikai arba paplintant žemdirbystei. Tai ir turètų būti atlikta būsimose studijose.

Donkalnio kapo 7 atvejis atskleidè, kaip reikšmingai genetika gali sustiprinti ${ }^{87} \mathrm{Sr} /{ }^{86} \mathrm{Sr}$ santykio interpretacijas. Stroncio izotopų analizè rodo, kad kape palaidotas maždaug $50 \mathrm{~m}$. vyras (cal BC 3521-3371) yra nevietinis, atvykęs tikriausiai iš pietų Suomijos arba Karelijos. Šio individo genomo duomenys rodo gerokai daugiau paveldimumo iš rytų medžiotojų-rinkejjų, palyginti su kitais Donkalnio ir Spigino žmonèmis (Mittnik et al. 2018). Rytų medžiotojų-rinkèjų genomo šaltiniu yra laikoma rytų Baltijoje buvusi Šukinès-duobelinès keramikos kultūra, kurios ekspansija datuojama 3900-3500 cal BC (Nordqvist 2018). Archeologinè medžiaga liudija buvus aktyvius ryšius tarp ŠV Rusijos ir PR Baltijos IV tūkstantm. cal BC. Tuomet vyko prekyba gintaro, skalūno, titnago žaliava ir dirbiniais dideliais atstumais. Lietuvoje yra randama pavienių grynų Šukinès-duobelinès keramikos kompleksų; jos formos ir puošybos elementai buvo kopijuojami ir perkeliami i vietinę porètąją keramiką (Piličiauskas et al. 2019). Taigi, stroncio izotopų ir ankstesni genetiniai tyrimai patvirtina, kad tarp Karelijos ir PR Baltijos daiktai ir technologijos nekeliavo be žmonių. Migravo žmonès, jie kūrè mišrias šeimas, o vèliau palaikè ryšius su gimtine.

Vis dèlto stroncio izotopu metodas turi ir klystkelių. Juo paremtos įžvalgos apie žmonių kilmę labai priklauso nuo to, kaip gerai yra pažistama biologiškai prieinamo stroncio ${ }^{87} \mathrm{Sr} /{ }^{86} \mathrm{Sr}$ variacija tiriamame regione. Jeigu ateityje paaiškètų, kad Latvijoje ir Baltarusijoje, o galbūt net ir Lietuvoje, yra didesnių „salų“, kur Sr... santykio vertès daugiau kaip 0,72, tuomet imtų klibėti šiame straipsnyje 


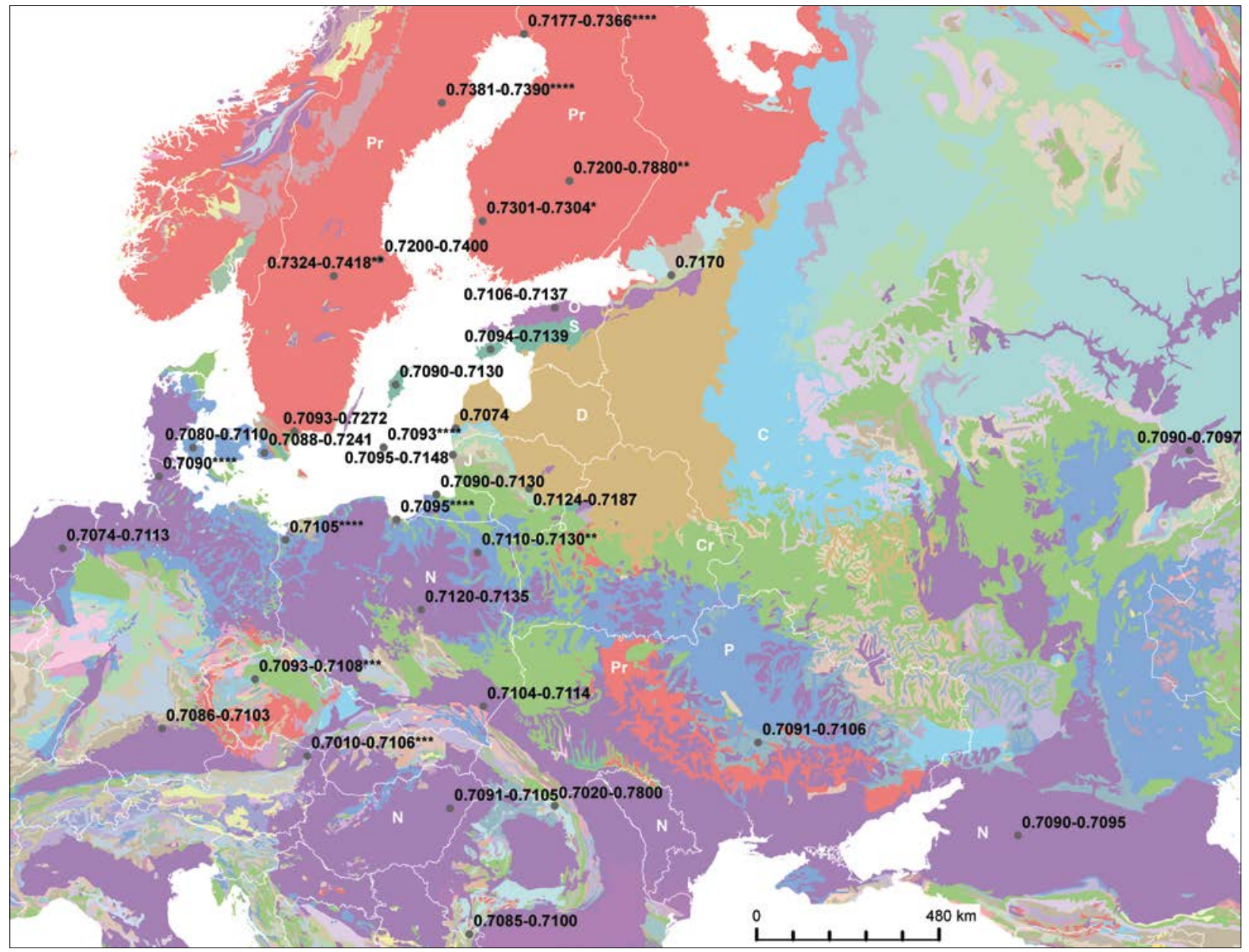

5 pav. ${ }^{87} \mathrm{Sr} /{ }^{86} \mathrm{Sr}$ santykio vertès rytų ir vidurio Europos geologiniame žemėlapyje. Geologinis pagrindas paimtas iš IGME5000 (2005). N - Neogenas, P - Paleogenas, Cr - Kreida, J - Jura, T - Triasas, C - Karbonas, D - Devonas, S - Silūras, O - Ordovikas, $\operatorname{Pr}-\operatorname{Prekambras} .{ }^{87} \mathrm{Sr} /{ }^{86} \mathrm{Sr}$ vertès be žvaigždučių yra gautos iš archeologinių gyvūnų, ${ }^{*}-$ iš žmonių emalio, ${ }^{* *}$ - iš gruntinio vandens, ${ }^{* * *}$ - iš žmonių dentino, ${ }^{* * * *}$ - iš paviršinio vandens (Åberg, Wickman 1987; Ahlström, Price 2021; Andersson et al. 1992; Bäckström, Price 2016; Bentley, Knipper 2005; Bergerbrant et al. 2017; Bläuer et al. 2013; Boric, Price 2013; Fraser et al. 2018; Frei et al. 2019; Frei, Frei 2011; Gerling 2015; Kootker et al. 2019; Löfvendahl et al. 1990; Oras et al. 2016; Piličiauskas et al., rengiama; Piličiauskienè et al., rengiama; Pospieszny et al. 2015; Price et al. 2004; 2018; 2020; Szczepanek et al. 2018; Voerkelius et al. 2010). G. Piličiausko brèž.

Fig. 5. ${ }^{87} \mathrm{Sr} /{ }^{86} \mathrm{Sr}$ ratios plotted onto a Pre-Quaternary geological map of Eastern and Central Europe. Geological layers have been taken from IGME5000 (2005). N - Neogene, P - Paleogene, Cr - Cretaceous, J - Jurassic, T - Triassic, C - Carboniferous, D Devonian, S - Silurian, O - Ordovician, $\mathrm{Pr}$ - Precambrian. ${ }^{87} \mathrm{Sr} /{ }^{86} \mathrm{Sr}$ ratios without a symbol are measured from archaeological fauna, ${ }^{*}$ denotes ratios from archaeological human enamel, ${ }^{* *}$ from ground water, ${ }^{* * *}$ from archaeological human dentine, ${ }^{* * * *}$ from surface water (Åberg and Wickman 1987; Ahlström and Price 2021; Andersson et al. 1992; Bäckström and Price 2016; Bentley and Knipper 2005; Bergerbrant et al. 2017; Bläuer et al. 2013; Boric and Price 2013; Fraser et al. 2018; Frei and Frei 2011; Frei et al. 2019; Gerling 2015; Kootker et al. 2019; Löfvendahl et al. 1990; Oras et al. 2016; Piličiauskas et al. in prep; Piličiauskienė et al. in prep; Pospieszny et al. 2015; Price et al. 2004; 2018; 2020; Szczepanek et al. 2018; Voerkelius et al. 2010). Drawing by G. Piličiauskas 
pasiūlyta Donkalnio 2 ir 7 kapuose palaidotų žmonių interpretacija, kildinanti minètus individus iš pietų Suomijos arba Karelijos. Šiandien yra labai mažai ${ }^{87} \mathrm{Sr} /{ }^{86} \mathrm{Sr}$ duomenų iš Kaliningrado srities, Latvijos, Baltarusijos, ŠV Rusijos (5 pav.). Nors ${ }^{87} \mathrm{Sr} /{ }^{86} \mathrm{Sr}$ santyki labai apytiksliai galima nuspèti iš geologijos, tačiau tai netikslu ir gerokai apsunkina nevietinių Lietuvos akmens amžiaus individų kilmès paiešką. Netrukus dviejų Lietuvoje vykdytų mokslinių projektų, kurie rèmèsi stroncio izotopų analize, rezultatai bus paskelbti tarptautiniuose leidiniuose anglų kalba. Tai galètų kaimyninių kraštų archeologams atverti akis, kokị didžiulị potencialą turi šis metodas, ypač taikant daugybinius vieno danties ${ }^{87} \mathrm{Sr} /{ }^{86} \mathrm{Sr}$ santykio matavimus (LA-MC-ICPMS). Archeologiniai ir genetiniai tyrimai, taip pat pirmieji stroncio izotopu tyrimai Lietuvoje rodo, kad priešistorèje žmonès judèjo daug ir toli, tad, norint tiksliau ir patikimiau nustatyti nevietinių individų kilmę, dabar yra reikalingi stroncio izotopų tyrimai kaimyninèse šalyse.

\section{ŠALTINIŲ IR LITERATŪROS SĄRAŠAS}

Åberg, G., Wickman, F. E., 1987. Variations of ${ }^{87} \mathrm{Sr} /{ }^{86} \mathrm{Sr}$ in water from streams discharging into the Bothnian Bay, Baltic Sea. Nordic Hydrology, 18, 33-42.

Ahlström, T., Price, D. T., 2021. Mobile or stationary? An analysis of strontium and carbon isotopes from Västerbjers, Gotland, Sweden. Journal of Archaeological Science: Reports, 36, 102902. DOI: https://doi.org/10.1016/j.jasrep.2021.102902.

Aleksa, P., 2007. Kvartero nuogulų storis Lietuvoje. Geologijos akiračiai, 1, 64-68.

Allentoft, M. E., Sikora, M., Sjögren et al. 2015. Population genomics of Bronze Age Eurasia. Nature, 522, 167-172.

Alonzi, E., Pacheco-Forés, S., Gordon, G. W., et al. 2020. New understandings of the Sea Spray Effect and its impact on bioavailable radiogenic strontium isotope ratios in coastal environments. Journal of Archaeological Science: Reports, 33, 102-452.

Andersson, P. S., Wasserburg, G. J., Ingri, J., 1992. The sources and transport of $\mathrm{Sr}$ and $\mathrm{Nd}$ isotopes in the Baltic Sea. Earth and Planetary Science Letters, 113, 459-472.

Antanaitis-Jacobs, I., Richards, M., Daugnora, L., et al. 2009. Diet in early Lithuanian prehistory and the new stable isotope evidence. Archaeologia Baltica, 12, 12-30.

Bäckström, Y., Price, D., 2016. Social identity and mobility at a preindustrial mining complex, Sweden. Journal of Archaeological Science, 66, 154-168.

Balasse, M., 2002. Reconstructing dietary and environmental history from enamel isotopic analysis: Time resolution of intra-tooth sequential sampling. International Journal of Osteoarchaeology, 12, 155-165.

Balasse, M., 2003. Potential biases in sampling design and interpretation of intra-tooth isotope analysis. International Journal of Osteoarchaeology, 13, 3-10.

Bentley, R. A., 2006. Strontium isotopes from the earth to the archaeological skeleton: a review. Journal of Archaeological Method and Theory, 13(3), 135-187.

Bentley, R. A., Knipper, C., 2005. Geographic patterns in biologically-available strontium, carbon and oxygen isotopes signatures in prehistoric SW Germany. Archaeometry, 47, 629-644.

Bergerbrant, S., Kristiansen, K., Allentoft, M. E., et al. 2017. Identifying commoners in the Early Bronze Age: burials outside barrows. In: Bergerbrant, S., Wessman A., (eds). New Perspectives on the Bronze Age. Oxford: Archaeopress Publishing, 37-64.

Bläuer, A., Korkeakoski-Väisänen, K., Arppe, L., Kantanen, J., 2013. Bronze Age cattle teeth and cremations from a monumental burial cairn in Selkäkangas, Finland: new radiocarbon dates and isotopic analysis. Estonian Journal of Archaeology, 17, 3-23.

Boethius, A., Kjällquist, M., Kielman-Schmitt, M., et al. 2021. Early Holocene Scandinavian foragers on 
a journey to affluence: Mesolithic fish exploatation, seasonal abundance and storage investigated through strontium isotope ratios by laser ablation (LA-MCICP-MS). PLoS ONE, 16(1), e0245222.

Boric, D., Price, T. D., 2013. Strontium isotopes document greater human mobility at the start of the Balkan Neolithic. Proceedings of the National Academy of Sciences, 110, 3298-3303.

Boulton, G. S., Dongelmans, P., Punkari, M., Broadgate, M., 2001. Palaeoglaciology of an ice sheet through a glacial cycle: the European ice sheet through the Weichselian. Quaternary Science Reviews, 20, 591-625.

Bramanti, B., Thomas, M. G., Haak, W., et al. 2009. Genetic discontinuity between local huntergatherers and central Europe's first farmers. Science, 326(5949), 137-140.

Bronk Ramsey, C., 2009. Bayesian analysis of radiocarbon dates. Radiocarbon, 51(1), 337-360.

Butrimas, A., 1992. Spigino mezolito kapai. Lietuvos archeologija, 8, 4-9.

Butrimas, A., 2019. Biržulis. Medžiotojai, žvejai ir senieji žemdirbiai X-II tūkstantmetyje pr. Kr. I. Paminklu tyrinejimai. Vilnius: Vilniaus dailès akademijos leidykla.

Butrimas, A., Kunskas, R., Česnys, G., et al. 1985. Duonkalnis: vèlyvojo neolito gyvenvieté, alkas ir kapinynas. Lietuvos archeologija, 4, 25-66.

Butrimas, A., Ostrauskienė, D., 2004. Biržulio apyežerio neolito gyvenviečių virvelinè keramika. Acta Academiae Artium Vilnensis, 34, 121-144.

Cramer, B. D., Munnecke, A., Schofield, D. I., et al. 2011. A revised ${ }^{87} \mathrm{Sr} /{ }^{86} \mathrm{Sr}$ curve for the Silurian: Implications for global ocean chemistry and the Silurian timescale. The Journal of Geology, 119(4), 335-349.

Diener, A., Ebneth, S., Veizer, J., Buhl, D., 1996. Strontium isotope stratigraphy of the Middle Devonian: brachiopods and conodonts. Geochimica et Cosmochimica Acta, 60(4), 639-652.
Edwards, C. T., Saltzman, M. R., Leslie, S. A., et al. 2015. Strontium isotope $\left({ }^{87} \mathrm{Sr} /{ }^{86} \mathrm{Sr}\right)$ stratigraphy of Ordovician bulk carbonate: Implications for preservation of primary seawater values. Bulletin, 127(9-10), 1275-1289.

Ericson, J. E., 1985. Strontium isotope characterization in the study of prehistoric human ecology. Journal of Human Evolution, 14(5), 503-514.

Fraser, M., Sjödin, P., Sanchez-Quinto, F., et al. 2018. The stone cist conundrum: A multidisciplinary approach to investigate Late Neolithic / Early Bronze Age population demography on the island of Gotland. Journal of Archaeological Science: Reports, 20, 324-337.

Frei, K. M., Frei, R., 2011. The geographic distribution of strontium isotopes in Danish surface waters - A base for provenance studies in archaeology, hydrology and agriculture. Applied geochemistry, 26(3), 326-340.

Frei, K. M., Bergerbrant, S., Sjögren, K. G., et al. 2019. Mapping human mobility during the third and second millennia BC in present-day Denmark. PLoS ONE, 14, e0219850.

Gerling, C., 2015. Prehistoric mobility and diet in the West Eurasian steppes 3500 to 300 BC: An isotopic approach. Berlin: Walter de Gruyter $\mathrm{GmbH}$.

Glykou, A., Eriksson, G., Storå, J., et al. 2018. Intra-and inter-tooth variation in strontium isotope ratios from prehistoric seals by laser ablation multicollector inductively coupled plasma mass spectrometry. Rapid Communications in Mass Spectrometry, 32(15), 1215-1224.

Gregoricka, L. A., 2013. Residential mobility and social identity in the periphery: strontium isotope analysis of archaeological tooth enamel from southeastern Arabia. Journal of Archaeological Science, 40(1), 452-464.

Haak, W., Lazaridis, I., Patterson, N., et al. 2015. Massive migration from the steppe was a source for Indo-European languages in Europe. Nature, 518, 284-285. 
Holt, E., Evans, J. A., Madgwick, R., 2021. Strontium $\left({ }^{87} \mathrm{Sr} /{ }^{86} \mathrm{Sr}\right)$ mapping: a critical review of methods and approaches. Earth-Science Reviews, 216, 103-593.

IGME5000, 2005. International Geological Map of Europe 1:5 Million and Adjacent Areas (IGME5000). Prieiga per: http://www.europe-geology. eu/onshore-geology/geological-map/igme5000/ [Žiūrèta 20210614 ].

Knudson, K. J., Pestle, W. J., Torres-Rouff, C., Pimentel, G., 2012. Assessing the life history of an Andean traveller through biogeochemistry: stable and radiogenic isotope analyses of archaeological human remains from Northern Chile. International Journal of Osteoarchaeology, 22(4), 435-451.

Kootker, L., van Lanen, R., Groenewoudt, B., et al. 2019. Beyond isolation: Understanding past human-population variability in the Dutch town of Oldenzaal through the origin of its inhabitants and its infrastructural connections. Archaeological and Anthropological Sciences, 11, 755-775.

Kudaba, Č., 1983. Lietuvos aukštumos. Vilnius: Mokslas.

Lazzerini, N., Balter, V., Coulon, A., et al. 2021. Monthly mobility inferred from isoscapes and laser ablation strontium isotope ratios in caprine tooth enamel. Scientific Reports, 11, 2277. DOI: https://doi. org/10.1038/s41598-021-81923-z.

Lietuvos geologijos tarnyba, 2021. Geomorfologinis žemèlapis $M 1: 200$ 000. Prieiga per: https://www. lgt.lt/zemelap/main.php?sesName=lgt1623915933 [Žiūrèta 202106 14].

Löfvendahl, R., Åberg, G., Hamilton, P. J., 1990. Strontium in rivers of the Baltic Basin. Aquatic Sciences, 52(4), 315-329.

Massler, M., Schour, I., Poncher, H. G., 1941. Developmental pattern of the child as reflected in the calcification pattern of the teeth. American Journal of Diseases of Children, 62(1), 33-67.

Mathieson, I., Alpaslan-Roodenberg, S., Posth, C., et al. 2018. The genomic history of southeastern Europe. Nature, 555, 197-203.
McArthur, J. M., Howarth, R. J., Bailey, T. R., 2001. Strontium isotope stratigraphy: LOWESS version 3: best fit to the marine Sr-isotope curve for 0-509 Ma and accompanying look-up table for deriving numerical age. The Journal of Geology, 109(2), 155-170.

Mittnik, A., Wang, C.-C., Pfrengle, S., et al. 2018. The genetic prehistory of the Baltic Sea region. Nature Communication, 9 (442), doi:10.1038/ s41467-018-02825-9.

Montgomery, J., 2010. Passports from the past: Investigating human dispersals using strontium isotope analysis of tooth enamel. Annals of human biology, 37(3), 325-346.

Nordqvist, K., 2018. The Stone Age of north-eastern Europe 5500-1800 cal BC. Bridging the gap between the East and the West (=Acta Universitatis Ouluensis, $B$ Humaniora 160). Oulu: University of Oulu.

Olalde, I., Brace, S., Allentoft, M. E., et al. 2018. The Beaker phenomenon and the genomic transformation of northwest Europe. Nature, 555, 190-196.

Oras, E., Lang, V., Rannamäe, E., et al. 2016. Tracing prehistoric migration: Isotope analysis of Bronze and Pre-Roman Iron Age coastal burials in Estonia. Estonian Journal of Archaeology, 20(1), 3-32.

Piličiauskas, G., 2018. Virvelinès keramikos kultūra Lietuvoje 2800-2400 cal BC. Vilnius: Lietuvos istorijos institutas.

Piličiauskas, G., Heron, C., 2015. Aquatic radiocarbon reservoir offsets in the southeastern Baltic. Radiocarbon, 57(4), 539-556.

Piličiauskas, G., Jankauskas, R., Piličiauskienè, G., Dupras, T., 2017a. Reconstructing Subneolithic and Neolithic diets of the inhabitants of the SE Baltic coast (3100-2500 cal BC) using stable isotope analysis. Archaeological and Anthropological Sciences, 9(7), 1421-1437.

Piličiauskas, G., Jankauskas, R., Piličiauskienè, G., et al. 2017b. The transition from foraging to farming (7000-500 cal BC) in the SE Baltic: A re-evaluation of chronological and palaeodietary evidence from 
human remains. Journal of Archaeological Science: Reports, 14, 530-542.

Piličiauskas, G., Kisielienė, D., Piličiauskienè, G., et al. 2019. Comb Ware culture in Lithuania: new evidence from Šventoji 43. Lietuvos archeologija, 45, 43-96.

Pospieszny, Ł., Sobkowiak-Tabaka, I., Price, T. D., et al. 2015. Remains of a late Neolithic barrow at Kruszyn. A glimpse of ritual and everyday life in early Corded Ware societies of the Polish Lowland. Praehistorische Zeitschrift, 90(1-2), 185-213.

Price, T. D., Grupe, G., Schröter, P., 1994. Reconstruction of migration patterns in the Bell Beaker period by stable strontium isotope analysis. Applied Geochemistry, 9(4), 413-417.

Price, T. D., Knipper, C., Grupe, G., Smrcka, V., 2004. Strontium isotopes and prehistoric human migration: the Bell Beaker period in central Europe. European Journal of Archaeology, 7(1), 9-40.

Price, T. D., Arcini, C., Gustin, I., et al. 2018. Isotopes and human burials at Viking Age Birka and the Mälaren region, east central Sweden. Journal of Anthropological Archaeology, 49, 19-38.

Price D. T., Peets J., Allmäe R., et al. 2020. Human remains, context, and place of origin for the Salme, Estonia, boat burials. Journal of Anthropological Archaeology. Vol. 58, 101-149.

Reid, D. J., Dean, M. C., 2006. Variation in modern human enamel formation times. Journal of $\mathrm{Hu}$ man Evolution, 50, 329-346.

Reimer, P. J., Austin, W. E., Bard, E., et al. 2020. The IntCal20 Northern Hemisphere radiocarbon age calibration curve (0-55 cal kBP). Radiocarbon, 62(4), 725-757.

Saag, L., Vasilyev, S. V., Varul, L., et al. 2021. Genetic ancestry changes in Stone to Bronze Age transition in the East European plain. Science Advances, 7(4), p.eabd6535.

Shaw, B., Buckley, H., Summerhayes, G., A., et al. 2010. Migration and mobility at the Late Lapita site of Reber-Rakival (SAC), Watom Island using isotope and trace element analysis: a new insight into Lapita interaction in the Bismarck Archipelago. Journal of Archaeological Science, 37(3), 605-613.

Snoeck, C., 2014. Impact of strontium sea spray effect on the isotopic ratio $\left({ }^{87} \mathrm{Sr} /{ }^{86} \mathrm{Sr}\right)$ of plants in coastal Ireland. Quaternary Newsletter, 134, 37-39.

Szczepanek, A., Belka, Z., Jarosz, P., et al. 2018. Understanding Final Neolithic communities in south-eastern Poland: New insights on diet and mobility from isotopic data. PloS ONE, 13(12), e0207748.

Szostek, K., Mądrzyk, K., Cienkosz-Stepańczak, B., 2015. Strontium isotopes as an indicator of human migration-easy questions, difficult answers. Anthropological Review, 78(2), 133-156.

Veizer, J., Buhl, D., Diener, A., et al. 1997. Strontium isotope stratigraphy: potential resolution and event correlation. Palaeogeography Palaeoclimatology Palaeoecology, 132, 65-77.

Voerkelius, S., Lorenz, G. D., Rummel, S., et al. 2010. Strontium isotopic signatures of natural mineral waters, the reference to a simple geological map and its potential for authentication of food. Food Chemistry, 118(4), 933-940. 


\title{
DONKALNIO IR SPIGINO KAPINYNŲ AKMENS AMŽIAUS ŽMONIŲ KILMĖ IR MOBILUMAS STRONCIO IZOTOPŲ ANALIZĖS DUOMENIMIS
}

\author{
Gytis Piličiauskas, Edvardas Simčenka, Justina Kozakaitė, Žydrūnẻ Miliauskienė, \\ Giedrè Piličiauskienè, Harry Kenneth Robson
}

\section{Santrauka}

Stroncio izotopu $\left.{ }^{\left({ }^{8} \mathrm{Sr}\right.} /{ }^{86} \mathrm{Sr}\right)$ analizè jau daugiau nei 3 dešimtmečius sèkmingai taikoma tirti žmonių ir gyvūnų mobilumui praeityje. Metodo esmè - kad gyvi organizmai stroncị kaupia audiniuose, taip pat labai tvirtame dantų emalyje. Gyviems organizmams prieinamas stroncis ị vandenị ir dirvožemị patenka daugiausia iš dūlančių uolienų per augalus ir gyvūnus, $\mathrm{o}^{87} \mathrm{Sr} /{ }^{86} \mathrm{Sr}$ izotopų santykis išlieka pastovus. Analizuojant izotopų santyki žmogaus dantų emalyje ir lyginant su biologiškai prieinamo stroncio santykiu aplinkoje, imanoma nustatyti, ar individas gyveno tam tikrame regione, ar naudojo jo maistą tiriamam dančiui formuojantis. Be to, daugybiniai vieno danties tyrimai leidžia pažinti vidinę ${ }^{87} \mathrm{Sr} /{ }^{86} \mathrm{Sr}$ variaciją, kuri atspindi chronologinę seką ir gali padèti sužinoti, kaip žmonès ar gyvūnai judejo formuojantis dantų emaliui.

Naujausi genetiniai tyrimai įrodè, kad neolite ir bronzos amžiuje daugelyje Europos dalių, ịskaitant Lietuvą, vyko tolimos ir didelio masto žmonių migracijos. Stroncio izotopų metodas priešistorinio mobilumo studijoms irgi gali būti itin naudingas. Todèl 2020-2021 m. pradètas vykdyti mokslinis projektas Žmoniu mobilumas akmens ir bronzos amžiuje stabiliujų izotopu tyrimu duomenimis. Šiame straipsnyje pristatomi preliminarūs projekto rezultatai, aptariamas mezolito ir neolito individų iš Donkalnio ir Spigino kapinynų mobilumas ir galima kilmè.

${ }^{87} \mathrm{Sr} r{ }^{86} \mathrm{Sr}$ santykis žmonių ir gyvūnų dantų emalyje buvo išmatuotas Švedijos gamtos istorijos muziejaus Stokholme Geomokslų departamente. Taikyti 2 metodai: lazeriné abliacija - multikolektorius - induktyviai susietos plazmos masių spektrometrija (LA-MC-ICPMS) ir izotopų praskiedimas - terminès jonizacijos masių spektrometrija (ID-TIMS). Šiame straipsnyje pateikiamos 13-os mezolito žmonių ir 9 gyvūnų ${ }^{87} \mathrm{Sr} /{ }^{86} \mathrm{Sr}$ vertès. Pirmenybè teikta anksčiausiai susiformuojantiems nuolatiniams krūminiams dantims M1 ir M2, jų nesant, tirti krūminis M3 ir kaplys P2. Kadangi daugumos šių dantų emalis visiškai mineralizuojasi per pirmuosius 6 gyvenimo metus, emalio ${ }^{87} \mathrm{Sr} /{ }^{86} \mathrm{Sr}$ gali padèti nustatyti mobilumą ankstyvoje vaikysteje.

Donkalnio ir Spigino kapinynai buvo įkurti kadaise didžiulio Biržulio ežero salose. Spigine ištirti 4 kapai, o Donkalnyje aptikta 14 individų. Visų individų mityba anksčiau buvo tirta $\mathrm{C}$ ir $\mathrm{N}$ izotopu kaulo kolagene metodu (1 pav.). Biržulio regiono kraštovaizdis susiformavo per paskutini apledejimą ir ankstyvajame holocene (2 pav.). ${ }^{87} \mathrm{Sr} /{ }^{86} \mathrm{Sr}$ ledyninèse nuogulose yra ịvairus ir daugiausia priklauso nuo labai radiogeniškų, iš vidurio Švedijos ledyno atvilktų prekambro uolienų ir mažai radiogeniškų, vietinių jūrinių karbonatų santykio. Vis dèlto tik iš geologinès informacijos biosferos stroncio izotopų santykis yra nenuspèjamas, todèl reikèjo tirti aplinkos mèginius. Ištyrème 9 archeologiniu gyvūnų, aptiktų dviejose archeologinėse vietovėse, esančiose ne didesniu kaip $7,8 \mathrm{~km}$ atstumu nuo laidojimo vietų, dantų emalị (2 pav.; 1 lent.) ir nustatème Biržulio regiono biologiškai prieinamo stroncio ${ }^{87} \mathrm{Sr} /{ }^{86} \mathrm{Sr}$, kuris yra $0,7146 \pm$ 0,0021 (2 SD).

Išmatavome ${ }^{87} \mathrm{Sr} /{ }^{86} \mathrm{Sr}$ santykị 13 -os žmonių 193ose dantų linijose, vidutiniškai 15 vieno danties linijų 
(2 lent.). Nustatėme, kad vidinę variaciją parodanti standartinè deviacija (SD) skirtingų individų svyruoja tarp 0,0004 ir 0,0023 (4 pav.). Manome, ${ }^{87} \mathrm{Sr} /{ }^{86} \mathrm{Sr}$ variacijos viename dantyje SD rodo individo mobilumą, o ciklinè variacija - sezoninị judejimą. Vidutinè ir didelè variacija dantyje $(0,0008-0,0023)$ rodo, kad mezolito ir subneolito individai greičiausiai negyveno sèsliai net ir didelio, seklaus ir labai žuvingo Biržulio ežero pakrantėse. Visi žemyne gyvenę medžiotojairankiotojai buvo mobilūs, ịskaitant ir tuos, kurie vertèsi žvejyba. Mažiausia ${ }^{87} \mathrm{Sr} /{ }^{86} \mathrm{Sr}$ variacija $(\mathrm{SD}=$ $0,0004)$ išmatuota moters, palaidotos Donkalnio kape nr. 3, dantyje. Tikètina, kad ji gimė ir vaikystę praleido Baltijos pakranteje.

Pagal danties vidinès ${ }^{87} \mathrm{Sr} /{ }^{86} \mathrm{Sr}$ variacijos kreives ir jų santykị su regiono biosferinio ${ }^{87} \mathrm{Sr} /{ }^{86} \mathrm{Sr}$ fonu Donkalnio ir Spigino kapinynuose palaidotus žmones suskirsteme i 3 grupes: vietinius, nevietinius ir pusiau vietinius (3 lent.). Vietiniais vadinami individai, kurių vidine ${ }^{87} \mathrm{Sr} /{ }^{86} \mathrm{Sr}$ santykio variacija neviršija regiono fono $(0,7125-0,7167)$. Visa nevietinių individų ${ }^{87} \mathrm{Sr} /{ }^{86} \mathrm{Sr}$ santykio kreivè arba bent pirmieji matavimai yra už regiono fono (0,7125-0,7167), o pusiau vietinių pirmieji ${ }^{87} \mathrm{Sr} /{ }^{86} \mathrm{Sr}$ matavimai yra tarp Biržulio regiono fono $(0,7125-0,7167)$ ribų, tačiau kiti jau išeina už šių ribų. Spigine tiek mezolito (kapas nr. 4), tiek neolito (kapas nr. 2) individų ${ }^{87} \mathrm{Sr} /{ }^{86} \mathrm{Sr}$ santykiai buvo vietiniai. Tačiau žymi vidinė variacija $(\mathrm{SD}=0,0008$; 3 pav.; 3 lent.) rodo gan dideli mobilumą ankstyvoje vaikystejje. Tikètina, kad jie visą gyvenimą nugyveno Biržulio regione arba gretimose teritorijose, kuriose biologiškai prieinamo stroncio ${ }^{87} \mathrm{Sr} /{ }^{86} \mathrm{Sr}$ yra panašus.
Donkalnyje 3 iš 11 tirtų žmonių (kapai nr. 2, 7 ir VI) pasirodè esantys nevietiniai. Šių asmenų ${ }^{87} \mathrm{Sr} /{ }^{86} \mathrm{Sr}$ santykis viršijo 0,72 , ir jie gali būti kilę iš pietų Suomijos arba Karelijos (5 pav.). İdomu, kad anksčiau atlikti genetiniai vieno nevietinio individo (kapas nr. 7; 3521-3371 cal BC) tyrimai nustate $30 \%$ paveldimumo iš rytų medžiotojų-rankiotojų, ir tai yra didžiausia proporcija tarp visų genetiškai tirtų Donkalnio ir Spigino individų. Rytų medžiotojųrankiotojų genomo šaltiniu yra laikoma Šukinèsduobelinès keramikos kultūra, kurios keramika ir akmens dirbiniai Baltijos rytiniame pakraštyje paplito 3900-3500 cal BC. Taigi, stroncio izotopu ir genetiniai tyrimai patvirtina, kad šios kultūros ekspansija neapsiejo be migracijos.

Dviejų Donkalnio individų (kapai nr. 3 ir 5) ${ }^{87} \mathrm{Sr} /{ }^{86} \mathrm{Sr}$ santykis buvo apie $0,711-0,712$. Jie prie Biržulio galèjo atkeliauti iš Baltijos pakrantès, kurioje dèl vadinamojo jūros purslų efekto biologiškai prieinamo stroncio ${ }^{87} \mathrm{Sr} /{ }^{86} \mathrm{Sr}$ yra mažai radiogeniškas. Šią interpretaciją paremia gintaro radiniai, rasti Biržulio ežero subneolito gyvenvietėse.

Dèl tolimų migracijų priešistorèje, taip pat dèl reikšmingos biologiškai prieinamo stroncio ${ }^{87} \mathrm{Sr} /{ }^{86} \mathrm{Sr}$ santykio variacijos erdveje metodas pasirodè esantis tinkamas identifikuoti pirmosios kartos migrantus net ir beveik ištisai ledynmečio nuogulomis padengtoje teritorijoje, kaip yra Lietuvoje. Tačiau jo galimybes riboja tai, kad yra labai mažai ${ }^{87} \mathrm{Sr} /{ }^{86} \mathrm{Sr}$ duomenų iš Kaliningrado srities, Latvijos, Baltarusijos, ŠV Rusijos (5 pav.). 


\title{
THE ORIGINS AND MOBILITY PATTERNS OF STONE AGE HUMANS FROM THE DONKALNIS AND SPIGINAS BURIAL GROUNDS ACCORDING TO STRONTIUM ISOTOPE ANALYSIS
}

\author{
Gytis Piličiauskas, Edvardas Simčenka, Justina Kozakaitė, Žydrūnè Miliauskienė, \\ Giedrè Piličiauskienè, Harry Kenneth Robson
}

\section{Summary}

Strontium $\left({ }^{87} \mathrm{Sr} /{ }^{86} \mathrm{Sr}\right)$ isotope analysis during the course of the last three decades has proved itself as a useful tool for assessing human and animal mobility in the past. The essence of the method lies in the ability of living organisms to incorporate trace element Sr into their tissues, including highly durable tooth enamel. Biologically available $\mathrm{Sr}$ originates mainly from eroded rocks, and the ${ }^{87} \mathrm{Sr} /{ }^{86} \mathrm{Sr}$ ratio does not change during transfer from bedrock to plants to humans. By analysing the isotopic ratios in human tooth enamel, and through comparison with data obtained from fauna, flora, water and soils, it is possible to identify mobility patterns and potential migration events. Moreover, high-resolution micro-sampling of a single tooth allows us to measure intra-tooth ${ }^{87} \mathrm{Sr} /{ }^{86} \mathrm{Sr}$ ratio variation which reflects a chronological sequence, and which can provide further insights in how humans or animals moved during tooth enamel formation.

Recent ancient DNA (aDNA) studies have demonstrated that large-scale and long-distance human migrations were commonplace throughout many parts of Europe, including Lithuania, during the Neolithic and the Bronze Age. A similarly useful method to identify past mobility patterns and migration events is strontium isotope analysis. Therefore, between 2020 and 2021 a research project was launched, Exploring human mobility during the Stone and Bronze ages using the analysis of stable isotopes, to explore prehistoric mobility in Lithuania. This paper presents the preliminary results of the project, and discusses the mobility patterns of Mesolithic and Neolithic individuals from the Donkalnis and Spiginas burial grounds in western Lithuania.

${ }^{87} \mathrm{Sr} /{ }^{86} \mathrm{Sr}$ ratios in human and animal tooth enamel were measured at the Swedish Museum of Natural History in Stockholm by laser ablationmulti collector-inductively coupled plasma-mass spectrometry (LA-MC-ICP-MS) and isotope dilutionthermal ionization mass spectrometry ID-TIMS. Here, we present the measurements obtained from 13 human and nine animal teeth. M1 and M2 human teeth were preferentially selected, whilst M3 and P2 were infrequently sampled. Since the enamel of the majority of these teeth mineralises completely during first 6 years of life, the results obtained from analysis by LA-MC-ICP-MS may help to identify the potential movement of individuals during early childhood.

During prehistory, the Donkalnis and Spiginas burial grounds were situated on islands in Lake Biržulis. At Spiginas four graves have been excavated, whilst 14 individuals are known from Donkalnis. The diet of all individuals has been previously investigated through the application of carbon and nitrogen stable isotope analysis (Fig. 1). The landscape of the Lake Biržulis region was formed during the last glaciation and Early Holocene (Fig. 2). The ${ }^{87} \mathrm{Sr} /{ }^{86} \mathrm{Sr}$ ratios in the glacial deposits vary, and mostly depend on the proportion between Precambrian rocks with high radiogenic Sr transported by ice sheets from 
middle Sweden, and local marine carbonates with low radiogenic Sr eroded by glaciers from pre-Quaternary deposits. Based on these data alone, the strontium baseline is unpredictable, and had to be ascertained by environmental samples. To do so, we analysed tooth enamel from nine archaeological animals from two sites situated up to a maximum distance of $7.8 \mathrm{~km}$ away from the burial grounds (Fig. 2; Table 1), and reconstructed the baseline for the Lake Biržulis region in the order of $0.7146 \pm 0.0021(2 \mathrm{SD})$.

For 13 human teeth we measured the ${ }^{87} \mathrm{Sr} /{ }^{86} \mathrm{Sr}$ ratios of 193 lines with an average of 15 lines per tooth (Table 2). We noted intra-tooth variation between 0.0004 and 0.0023 (Fig. 4). We suggest that this intra-tooth variation indicates a degree of mobility while cyclic variation reflects seasonal mobility. The evidenced moderate and high intra-tooth variation (0.00080.0023) shows that the Mesolithic and Subneolithic individuals probably did not live out their lives in sedentary settlements along the shoreline of the large, shallow and likely highly productive Lake Biržulis. Indeed, all inland hunters-gatherers were mobile, including those who engaged in fishing. The lowest intra-tooth variation (0.0004) was measured from an individual from the Donkalnis burial ground (Grave No. 3). It is likely that this individual probably spent their late childhood on the Baltic Sea coastline. It is expected that future research of individuals from the Baltic Sea coastline may exhibit 'more sedentary' ${ }^{87} \mathrm{Sr} /{ }^{86} \mathrm{~S}$ ratios given the highly productive and rich marine and lagoonal foodstuffs readily available.

Based on the aforementioned measurements we compiled curves of intra-tooth ${ }^{87} \mathrm{Sr} /{ }^{86} \mathrm{~S}$ ratio variation for every human individual (Fig. 3). According to the curves and their relationship with the local baseline we divided the humans into three groups: locals, non-locals and semi-locals (Table 3). We classified the locals based on little variation of their ${ }^{87} \mathrm{Sr} /{ }^{86} \mathrm{Sr}$ ratios that were within the range of the local baseline (0.7125-0.7167). Non-locals had all or their first
${ }^{87} \mathrm{Sr} /{ }^{86} \mathrm{~S}$ ratios outside the local baseline, whilst semilocals had their first ${ }^{87} \mathrm{Sr} /{ }^{86} \mathrm{~S}$ ratios within the local range but at some point their intra-tooth variation curves exceeded the lower or upper boundaries of the local baseline.

At Spiginas, both the Mesolithic (Grave No. 4) and Neolithic (Grave No. 2) individuals demonstrated local ${ }^{87} \mathrm{Sr} /{ }^{86} \mathrm{Sr}$ ratios. However, remarkable intraindividual variations $(\mathrm{SD}=0.0008$; Fig. 3 ; Table 3 ) indicate a rather mobile lifestyle during early childhood for both individuals. Despite this, it is likely that they lived out their lives within the Lake Biržulis region or adjacent areas with similar ${ }^{87} \mathrm{Sr} /{ }^{86} \mathrm{Sr}$ ratios of bioavailable strontium.

At Donkalnis, 3/11 humans (Grave Nos. 2, 7, and VI) appear to be non-local. Indeed, these individuals had ${ }^{87} \mathrm{Sr} /{ }^{86} \mathrm{Sr}$ ratios above 0.72 and may be derived from southern Finland or Karelia (Fig. 5). Intriguingly, aDNA analysis of one of the individuals (Grave No. 7; 3521-3371 cal BC) has previously demonstrated that the individual had a substantial part of their ancestry from Eastern Hunter-Gatherers (30\%), which markedly differs compared with the other Donkalnis and Spiginas individuals (0-10\%). The source of Eastern Hunter-Gatherers ancestry in the Eastern Baltic likely derives from the Comb Ware culture in which similar ceramics and stone tools were spread widely throughout the region between 3900-3500 cal BC. Building on the aDNA data, the strontium isotope analysis demonstrates that this spread also included long-distance mobility patterns.

Two individuals from Donkalnis (Grave Nos. 3 and 5) had ${ }^{87} \mathrm{Sr} /{ }^{86} \mathrm{Sr}$ ratios of between $c a .0 .711$ and 0.712 , and may have arrived at Lake Biržulis from the Baltic Sea coastline, which has a lower radiogenic strontium ratio due to the "sea spray effect". Numerous amber finds from the Lake Biržulis region are in line with this interpretation suggesting contacts and movement between the two areas during the Subneolithic period. 